\title{
Iranian Qara Qat fruit (redcurrant) in Arasbaran forests as the resource of anthocyanin pigments in formation of $\left[\mathrm{ACN}-\mathrm{Mg}^{2+} / \mathrm{Al}^{3+} / \mathrm{Ga}^{3+} / \mathrm{Sn}^{2+} /\right.$ $\left.\mathrm{Cr}^{3+} / \mathrm{Fe}^{3+}\right]$ chelation clusters
}

\author{
Fatemeh Mollaamin ${ }^{1}$ (D) Nayer T. Mohammadian ${ }^{2} \cdot$ Narges Najaflou $^{3} \cdot$ Majid Monajjemi $^{1}$
}

Received: 18 August 2020 / Accepted: 23 February 2021 / Published online: 2 March 2021

(C) The Author(s) 2021 OPEN

\begin{abstract}
Clusters of metallic cations $\left(\mathrm{Mg}^{2+}, \mathrm{Al}^{3+}, \mathrm{Ga}^{3+}, \mathrm{Sn}^{2+}, \mathrm{Cr}^{3+}\right.$ and $\left.\mathrm{Fe}^{3+}\right)$ jointed to anthocyanins in water media were studied for unraveling the color shifting of different complexes of these structures in the low ranges of $\mathrm{pH}$. Anthocyanin jointed to metallic cation progresses the color expression range of anthocyanin in more different range of $\mathrm{pH}$. In this verdict, it has been studied the metallic cations diffusing of deprotonating for the anthocyanin (B)-ring of cyanidin (Cy), delphinidin $(\mathrm{Dp})$ and petunidin $(\mathrm{Pt})$ in two media of gas and water, transforming flavylium cations to the blue quinonoidal bases at lower range of $\mathrm{pH}$ applying the infrared method by approaching Beer Lambert law for getting the physico-chemical parameters of frequency, intensity, and absorbance of the compounds, respectively. In previous investigation, it has been indicated that the important factor for enhancing the absorbance in a positive non-linear fashion due to deviating from the Beer Lambert law is the self-association of anthocyanins of cyanidin, delphinidin and petunidin of anthocyanin structures. The difference of heat of formation $\left(\Delta \mathrm{H}_{\mathrm{R}}\right)$ among clusters of metallic cations jointed to anthocyanins has been illustrated toward the double bonds and carbonyl groups by the chelation of (B)-ring for cyanidin, delphinidin and petunidin anthocyanins in two media of gas and water that explains the stability and color of [anthocyanin-metallic cations] cluster chelation of cyanidin (Cy), delphinidin (Dp) and petunidin (Pt) colorful pigments in a weak acidic medium. By this work we exhibited that the color of the anthocyanin chelates is an important factor for estimating the efficiency of these types of food colorants.
\end{abstract}

Keywords Iranian Qara Qat fruit · [anthocyanin-metallic cations of $\left(\mathrm{Mg}^{2+}, \mathrm{Al}^{3+}, \mathrm{Ga}^{3+}, \mathrm{Sn}^{2+}, \mathrm{Cr}^{3+}\right.$ and Fe$\left.{ }^{3+}\right)$ ] cluster chelation · Anthocyanin-metal chelate $\cdot$ Cyanidin (Cy) $\cdot$ Delphinidin (Dp) $\cdot$ Petunidin (Pt)

\section{Introduction}

The compounds of anthocyanin water soluble and polar derivatives which have a large membrane bound vesicle in a cell's cytoplasm can be seen in different colors in an expanded range of colors such as red, purple, blue or black [1-3]. The aromatic cyclic group of anthocyanins are a part of fundamental compounds as flavonoids synthesized via the phenyl propanoid pathway which are discovered in roots, stems, leaves, flowers, and fruits. The portion of the most common anthocyanidins in fruits and vegetables including cyanidin, delphinidin, pelargonidin, peonidin, malvidin, and petunidin is $50 \%, 12 \%, 12 \%$, $12 \%, 7 \%$, and $7 \%$, respectively [4]. In nature, cyanidin in berries is a reddish-purple major pigment and other redcolored vegetables such as red sweet potato and purple corn $[5,6]$. Delphinidin (Dp) has a chemical characteristic similar to most of the anthocyanidins which appears as a

$\triangle$ Fatemeh Mollaamin, smollaamin@gmail.com; $\bowtie$ Majid Monajjemi, maj.monajjemi@iauctb.ac.ir| ${ }^{1}$ Department of Chemical Engineering, Central Tehran Branch, Islamic Azad University, Tehran, Iran. ${ }^{2}$ Department of Chemistry, Ardabil Branch, Islamic Azad University, Ardabil, Iran. ${ }^{3}$ Department of Chemistry, Science and Research Branch, Islamic Azad University, Tehran, Iran. 
blue-reddish or purple pigment in the plant like the blue hue of flowers which is due to the delphinidin pigment [7]. But pelargonidin is different from most of the anthocyanidins as a red-colored pigment [8]. Besides, pelargonidin donates an orange hue to flowers and red to some of the fruits and berries $[9,10]$. The investigations on foods and plants consisting of antioxidant characteristics have begun toward indicating the multiple data exhibiting their effects in the reduction of risk through chronic sicknesses on the members in the world [11-14].

Fruits and vegetables have the chemical structures linked to health promotions showing several antioxidants like vitamins ( $\mathrm{C}$ and $\mathrm{E})$, carotenoids and flavonoids and their characteristics including molecular weight, dimensional conformation, biochemical and physical characteristics of these compounds conduct them to react with different points in many live organisms [15-17].

The most advantage of nutrition in anthocyanin pigments through the human life shows the ability of health benefits on various sicknesses like cancer, Alzheimer disease, obesity, neurological diseases, inflammation and diabetes. The compounds of anthocyanin pigments are a big family of polyphenolic molecules as flavonoids that are founded by plants as the part of their secondary metabolism. Flavonoids are divided into different subclasses based on their chemical characteristics and share a popular carbon basis called flavylium ion chain with different rings $[18,19]$.

The Glycosylated anthocyanidins groups which are linked to the skeleton of anthocyanin have the highest common type of pigments in plants. So, it can be found a variety of anthocyanins due to complex glycosylation models over some aglycones. These compounds are largely colored at low $\mathrm{pH}$, through the eight conjugated double bonds exhibiting a positive charge of the structure that show various colors due to various substitutions in the aromatic cyclic chains [20-24]. Physicochemical properties of anthocyanin structures are affected by the particle substitutions due to changing the size, polarity and solubility in water toward an expanded range of compounds in nature [25]. It is important how the plants arrange the structure or how chemistry of the anthocyanins produces an expanded range of colors often in the visible spectrum [26]. Moreover, for indicating the color and stability of anthocyanins through the chemical and other photochemical properties, several new anthocyanin-inspired dyes and pigments have been prepared for applying in cosmetics or foods with pleasant colors and stability in comparison to the color and stability of natural anthocyanins [27]. The scientists have explained that the color of natural anthocyanins is sensitive to concentration of hydrogen cation in the solution (weak acidic media are appropriate). Around " $\mathrm{pH}=3$ ", changing the color generates the colored anthocyanin cation, $\mathrm{AH}^{+}$, which alters into colorless or near-colorless samples (Scheme 1) [28].

Arasbaran vegetation zone is a very rich area in Iran which has most of Iran's herbaceous species including medicinal, ornamental and edible products. Most of the trees in this area are oak, kikem, crimson, barberry, wild pomegranate, wild apples, wild pears and raspberries, and cucumbers, along with fruits called Qara Qat (redcurrant), which is very tasty and sour, and are seasoned in the middle of summer (Scheme 1a). In acidic media, anthocyanin appears as a red pigment while blue pigment anthocyanin appears in alkaline media. Anthocyanin is considered as one of the flavonoids with a positive charge at the oxygen atom of the (C)-ring (Scheme $1 \mathrm{~b}$ ).

Glińska and his coworkers have illustrated the decrease of potential toxic effects of anthocyanins through separating metal cation chelation of these compounds [30]. For

(a)

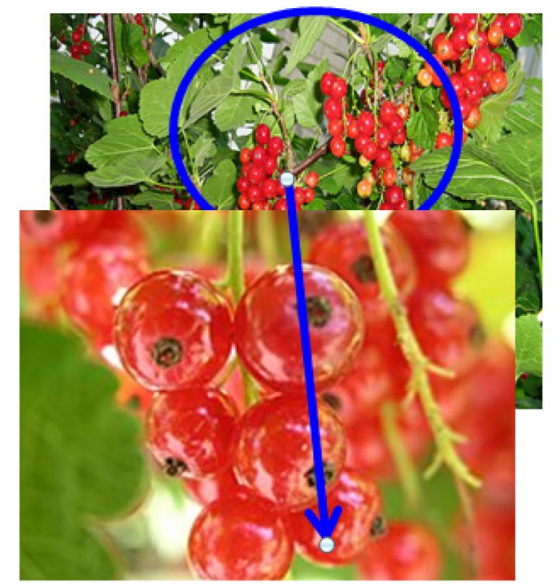

(b)

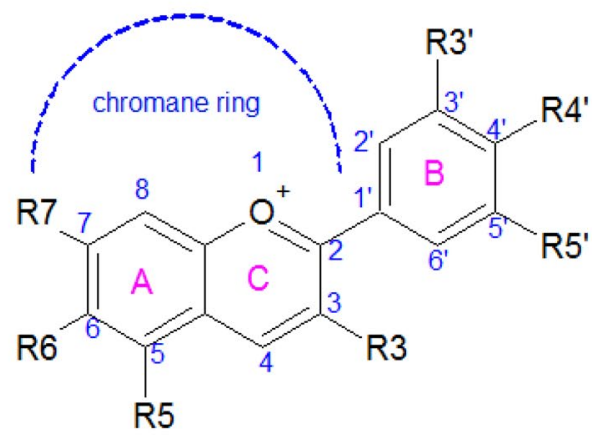

Scheme 1 a Qara Qat fruit (redcurrant) of Arasbaran vegetation in Iran, b Basic anthocyanin structure [28]

SN Applied Sciences

A SPRINGER NATURE journal 
being capable of forming metallic cation chelation and expressing purple blue colors, the molecule of anthocyanin must tolerate at least 2 free hydroxyl groups on the (B)-ring. When the cation approaches the anthocyanins, it plays a role to compete with the hydrogen ions for the binding sites (Scheme 2) [31].

The chelation of $\mathrm{Mg}^{2+}, \mathrm{Al}^{3+}, \mathrm{Ga}^{3+}, \mathrm{Sn}^{2+}, \mathrm{Cr}^{3+}$ and $\left.\mathrm{Fe}^{3+}\right)$ metallic cations by cyanidin, delphinidin and petunidin has been more extensively studied due to its relationship with the blue coloration of hydrangea floral compounds. Relatively, stable complexes between delphinidin and aluminum cation have been investigated to form acidified ethanol and a wide $\mathrm{pH}$ range [31]. In these structures, color expression of the delphinidin began red becoming violet and then blue as $\mathrm{pH}$ and anthocyanin concentration were maintained, but the aluminum cation content increased. Chelation of aluminum cation with cyanidin has been identified to develop in aqueous samples, $\mathrm{pH}(2-5)$ which indicate violet colorations [32].

The spectral responses of these cyanidin complexes jointed to metal cation chelation were more difficult to distinguish in the value of $\mathrm{pH} 7$ (Scheme 3). It has been obvious that large Bathochromic shifts have existed in the value of $\mathrm{pH} 6$, but the appeared changes in maximum $\lambda$ in<smiles>[R]c1cc(-c2[o+]c3cc(O)cc(O)c3cc2O)cc(O)c1O</smiles><smiles>[134I-]</smiles><smiles></smiles>

Ga3+

$\operatorname{Sn} 2+$

Cr3+

$\mathrm{Fe} 3+$<smiles>[R]C1=CC(C(=O)c2cc3cc(O)cc(O)c3cc2O)C=C2O[Y10](C)OC12</smiles><smiles></smiles><smiles>[R]C1=CC(C(=O)c2cc3cc(O)cc(O)c3cc2O)C=C2O[CH+]OC12</smiles><smiles></smiles><smiles></smiles><smiles>[R]C1=CC(C(=O)c2cc3cc(O)cc(O)c3cc2O)C=[O+]O1</smiles>

Scheme 2 Pigment clusters of anthocyanin-cation chelation including [anthocyanin-metallic cations of $\left(\mathrm{Mg}^{2+}, \mathrm{Al}^{3+}, \mathrm{Ga}^{3+}, \mathrm{Sn}^{2+}, \mathrm{Cr}^{3+}\right.$ and $\left.\mathrm{Fe}^{3+}\right)$ ] through the (B)-ring for three anthocyanins of Cyanidin, Delphinidin and Petunidin [31] 


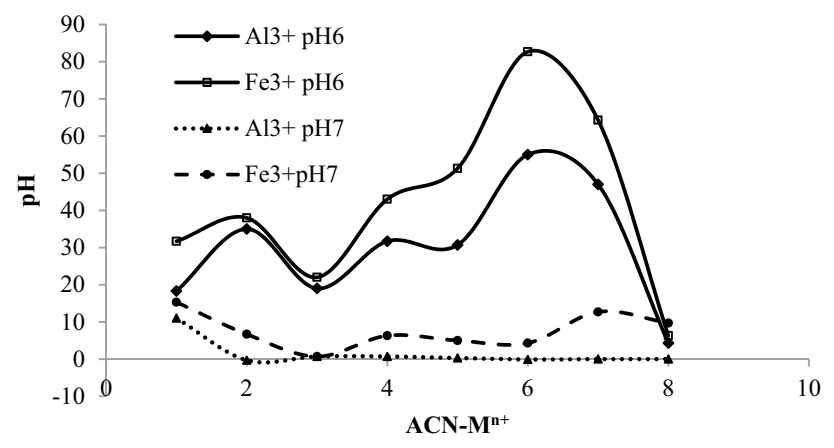

Scheme 3 The spectral responses of the cyanidin derivatives to metal ion chelation of $\mathrm{Al}^{3+} \& \mathrm{Fe}^{3+}$ in $\mathrm{pH}=7$. Buchweitz and his coworkers compared the stability of aluminum cation chelates of delphinidin-3-rutinoside in American eggplant to that of acylated cyanidin glycosides, red cabbage, as literature is limited about stability of acylated anthocyanin metal chelates

neutral $\mathrm{pH}$ were small specially with enhancing metal ion concentrations. Besides, the junction of anthocyanidins to $\mathrm{Fe}^{3+}$ cation was a little larger than to aluminum cation based on other investigations. Anthocyanins can gain a maximum amount of $\lambda$ by these chemical complexes based on the bathochromic replies. Anthocyanin has indicated the maximum value of $\lambda$ in the range of $\mathrm{pH}(7$, 8 ) and has showed the hypochromic replies in the higher $\mathrm{pH}[33,34]$.

It has been seen the changes in the observable absorption of the spectra for the colorful pigments existent in solution, but the changes of maximum $\lambda$ of anthocyanin by metallic cation chelation were small and sometimes negative (Scheme 3).

They explained that anthocyanin metallic complexes are stronger to heat treatment rather than light exposure. Degradation of delphinidin-aluminum chelates seems jointed to concentration with rate decreasing of time, in agreement with recent researches [35].

In the recent researches, it has been approved that aluminum cation in metalloanthocyanins is capable of inducing blue color development with delphinidin, having a pyrogallol moiety on the (B)-ring, but it is not enough to lead to blue colors with cyanidin derivatives [36].

Therefore, a theoretical study of the linkage between the electronic and chemical structure of $\left(\mathrm{Mg}^{2+}, \mathrm{Al}^{3+}, \mathrm{Ga}^{3+}\right.$, $\mathrm{Sn}^{2+}, \mathrm{Cr}^{3+}$ and $\mathrm{Fe}^{3+}$ ) metallic cations by cyanidin, delphinidin and petunidin and their stability has been followed using theoretical and computational methods in two media of gas and water at $300 \mathrm{~K}$ based considering Beer Lambert law for discovering different usages of these structures such as coloring agents in pharmaceutical products and foods. Moreover, it has been illustrated the structural properties of [anthocyanin-metallic cations of $\left(\mathrm{Mg}^{2+}\right.$, $\mathrm{Al}^{3+}, \mathrm{Ga}^{3+}, \mathrm{Sn}^{2+}, \mathrm{Cr}^{3+}$ and $\left.\left.\mathrm{Fe}^{3+}\right)\right]$ cluster chelation in Iranian
Qara Qat fruit by quantum chemical methodologies as the computational design and the simulated class to estimate the physicochemical characteristics of these chelated pigments with metal ions through conserving their stability and color tide.

\section{Perspective of cluster chelation}

The chelation of anthocyanins of cyanidin, delphinidin and petunidin with $\left(\mathrm{Mg}^{2+}, \mathrm{Al}^{3+}, \mathrm{Ga}^{3+}, \mathrm{Sn}^{2+}, \mathrm{Cr}^{3+}\right.$ and $\left.\mathrm{Fe}^{3+}\right)$ metallic cations in Iranian Qara Qat fruit has been studied in this investigation by forming relatively stable complexes in the weak acidified medium with a different $\mathrm{pH}$ range. Thus, a series of quantum theoretical approaches has been done for finding the optimized coordination of [anthocyaninmetallic cations of $\left(\mathrm{Mg}^{2+}, \mathrm{Al}^{3+}, \mathrm{Ga}^{3+}, \mathrm{Sn}^{2+}, \mathrm{Cr}^{3+}\right.$ and $\left.\left.\mathrm{Fe}^{3+}\right)\right]$ cluster chelation in Iranian Qara Qat fruit with IR computations and following the Beer lambert Rule using Gaussian09 program package [37].

It has been declared that polarization functions into the applied basis set in the computation always introduce us an important achievement on the modeling and simulation theoretical levels. Normal mode accomplishment is the verdict of harmonic potential wells by analytic methods which maintain the motion of all atoms at the same time in the vibration time scale leading to a natural explanation of molecular vibrations [38-43].

First, optimized geometry coordination of [cyanidinmetallic cations of $\left(\mathrm{Mg}^{2+}, \mathrm{Al}^{3+}, \mathrm{Ga}^{3+}, \mathrm{Sn}^{2+}, \mathrm{Cr}^{3+}\right.$ and $\left.\left.\mathrm{Fe}^{3+}\right)\right]$ cluster chelation in Iranian Qara Qat fruit (Fig. 1) through their (B)-ring in two media of gas and water at $300 \mathrm{~K}$ has been evaluated in Table 1.

Besides, charge electron transfer and thermodynamic properties of [anthocyanin-metallic cations of $\mathrm{Mgg}^{2+}, \mathrm{Al}^{3+}$, $\mathrm{Ga}^{3+}, \mathrm{Sn}^{2+}, \mathrm{Cr}^{3+}$ and $\left.\mathrm{Fe}^{3+}\right)$ ] cluster chelation in Iranian Qara Qat fruit through their (B)-ring in two media of gas and water at $300 \mathrm{~K}$ have been evaluated and compared to each other by different concentration of $\mathrm{H}^{+}$in a simulated solvent model (Fig. 2).

In this work, the data have been achieved from thermodynamic parameters of $\Delta \mathrm{G}, \Delta \mathrm{H}$ and $\Delta \mathrm{S}$ for the solute-solvent model of [anthocyanin-metallic cations of $\left(\mathrm{Mg}^{2+}, \mathrm{Al}^{3+}\right.$, $\mathrm{Ga}^{3+}, \mathrm{Sn}^{2+}, \mathrm{Cr}^{3+}$ and $\mathrm{Fe}^{3+}$ ] cluster chelation in Iranian Qara Qat fruit. The solved data at $300 \mathrm{~K}$ have been analyzed compared to gas phase.

Therefore, for accomplishing a stable structure of [anthocyanin-metallic cations of $\mathrm{Mgg}^{2+}, \mathrm{Al}^{3+}, \mathrm{Ga}^{3+}, \mathrm{Sn}^{2+}$, $\mathrm{Cr}^{3+}$ and $\left.\mathrm{Fe}^{3+}\right)$ ] cluster chelation of cyanidin, delphinidin, and petunidin of colorful pigments in Iranian Qara Qat fruit, geometry optimization plus frequency calculations were done; the frequency and intensity of the vibrational modes were calculated with the quantum mechanics of 

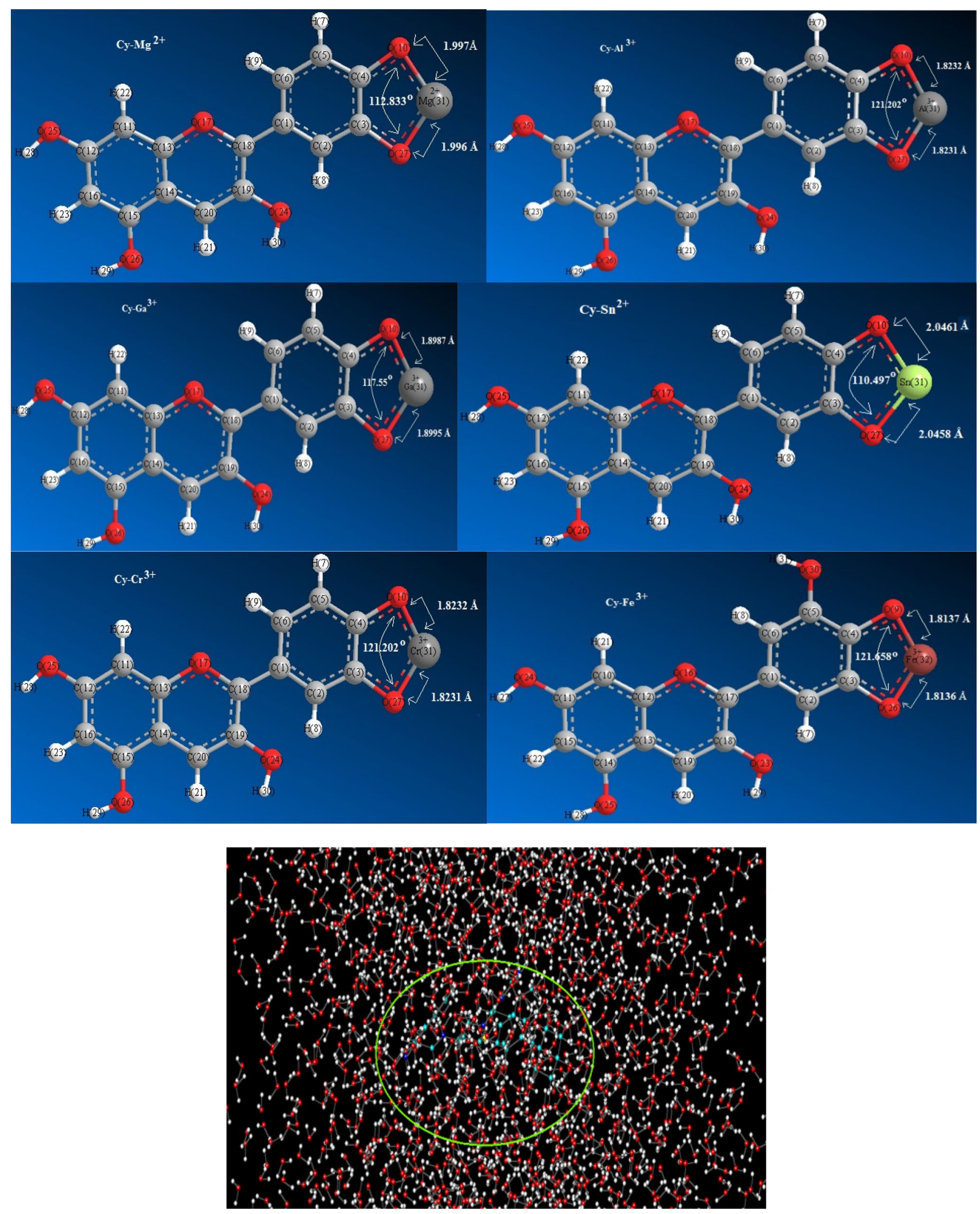

Fig. 1 The schematics of ab initio optimized coordination [anthocyanin-metallic cations of $\left(\mathrm{Mg}^{2+}, \mathrm{Al}^{3+}, \mathrm{Ga}^{3+}, \mathrm{Sn}^{2+}, \mathrm{Cr}^{3+}\right.$ and $\left.\left.\mathrm{Fe}^{3+}\right)\right]$ through representing the bond length of oxygen- $\mathrm{M}^{\mathrm{n}+}$ and bond angle of oxygen- $\mathrm{M}^{\mathrm{n}+}$-oxygen calculated by $\mathrm{m} 062 \mathrm{x} / \mathrm{cc}-\mathrm{pvdz}$ pseudo $=\operatorname{lan} 12$ in solvation optimized with $\mathrm{QM} / \mathrm{MM}$ model of anthocyanins' family inside 500 water molecules as solvent, including 3 levels of m06-HF for the high $(\mathrm{H})$ layer, Pm3MM semi empirical for the medium and Monte Carlo for low layers at $300 \mathrm{~K}$ 
Table 1 Optimized geometry with $\mathrm{m} 062 \mathrm{x} / \mathrm{cc}-\mathrm{pvdz}$ pseudo $=\operatorname{lan} 12$ for various [anthocyanin-metallic cations of $\left(\mathrm{Mg}^{2+}, \mathrm{Al}^{3+}, \mathrm{Ga}^{3+}, \mathrm{Sn}^{2+}, \mathrm{Cr}^{3+}\right.$ and $\left.\mathrm{Fe}^{3+}\right)$ ] cluster chelation in Iranian Qara Qat fruit extracted of Fig. 1

\begin{tabular}{|c|c|c|c|c|}
\hline $\begin{array}{l}\text { Cyanidin-metal } \\
\text { ion chelate }\end{array}$ & Bond length & $(\AA)$ & Bond angle & $\theta^{0}$ \\
\hline \multirow[t]{2}{*}{$\mathrm{Cy}-\mathrm{Mg}^{2+}$} & $\mathrm{O}(10)-\mathrm{Mg}^{2+}(31)$ & 1.997 & $\mathrm{O}(10)-\mathrm{Mg}^{2+}(31)-\mathrm{O}(27)$ & 112.833 \\
\hline & $\mathrm{Mg}^{2+}(31)-\mathrm{O}(27)$ & 1.996 & & \\
\hline \multirow[t]{2}{*}{$\mathrm{Cy}-\mathrm{Al}^{3+} / \mathrm{Cr}^{3+}$} & $\mathrm{O}(10)-\mathrm{Al}^{3+} / \mathrm{Cr}^{3+}(31)$ & 1.8232 & $\mathrm{O}(10)-\mathrm{Al}^{3+} / \mathrm{Cr}^{3+}(31)-\mathrm{O}(27)$ & 121.202 \\
\hline & $\mathrm{Al}^{3+} / \mathrm{Cr}^{3+}(31)-\mathrm{O}(27)$ & 1.8231 & & \\
\hline \multirow[t]{2}{*}{$\mathrm{Cy}-\mathrm{Fe}^{3+}$} & $\mathrm{O}(9)-\mathrm{Fe}^{3+}(32)$ & 1.8137 & $\mathrm{O}(10)-\mathrm{Fe}^{3+}(31)-\mathrm{O}(27)$ & 121.658 \\
\hline & $\mathrm{Fe}^{3+}(32)-\mathrm{O}(26)$ & 1.8136 & & \\
\hline \multirow[t]{2}{*}{$\mathrm{Cy}-\mathrm{Ga}^{3+}$} & $\mathrm{O}(10)-\mathrm{Ga}^{3+}(31)$ & 1.8987 & $\mathrm{O}(10)-\mathrm{Ga}^{3+}(31)-\mathrm{O}(27)$ & 117.55 \\
\hline & $\mathrm{Ga}^{3+}(31)-\mathrm{O}(27)$ & 1.8995 & & \\
\hline
\end{tabular}

theoretical method, and the principal vibrational modes were analyzed by their changes of Gibbs free energy in water compared to water medium at $300 \mathrm{~K}$. Thermochemistry analysis follows the frequency and normal mode data. The zero-point energy output in Gaussian-09 has been expanded and corrected as: thermal correction to energy, thermal correction to enthalpy and thermal correction to the Gibbs free. In addition the total energies can be calculated as: sum of electronic and zero point energies, sum of electronic and thermal energies, sum of electronic and thermal enthalpies and sum of electronic and thermal Gibbs free energies. The theoretical calculations were done at various levels of theory to gain the more accurate equilibrium geometrical results and IR spectral data for each of the identified compounds. It is supposed that an additional diffuse and polarization functions into the basis set applied in the computation conduct us to the magnificent progress on the results of theoretical methods. The simulation indicates the approaches which produce a common template of a model at a special temperature by computing all physicochemical properties among the partition function [39].

\section{Computational details}

In this work, molecular dynamics, (MD), methods produce a series of time-correlated points in phase space in propagating a starting set of coordinates and velocities according to Newton's second equation by a series of finite time steps on [anthocyanin-metallic cations of $\mathrm{Mg}^{2+}, \mathrm{Al}^{3+}$, $\mathrm{Ga}^{3+}, \mathrm{Sn}^{2+}, \mathrm{Cr}^{3+}$ and $\left.\left.\mathrm{Fe}^{3+}\right)\right]$ cluster chelation in Iranian Qara Qat fruit. Unlike single point and geometry optimization calculations, molecular dynamics calculation account for thermal motion (Fig. 3). Molecular dynamics (MD) includes conformation theories, thermodynamic parameters and movement rules of the molecular machine and kinetic energy to the potential energy surface. If a set of initial situations is explained, then Newton's rules cause the molecular machine to raise a path that is indicated as the molecular dynamics path. This path climbs the potential level in ways that are of important interest to unravel. Both the final point of a path and the trajectory taken to get there are of credit in molecular modeling.

Molecular dynamics simulations, MD, estimate the future velocities and positions of atoms on the basis of their current velocities and positions. At first, the simulation identifies the force on an atom, Fi, as the function of time, toward a negative gradient of the potential energy (Eq. 1);

$\mathrm{F}_{\mathrm{i}}=\partial \mathrm{V} / \partial \mathrm{r}_{\mathrm{i}}$,

$V=$ function of potential energy and $r_{i}$ is the position of atom i. Then, we can distinguish the acceleration, ai, of an atom by dedicating the force action to it by the atom mass (Eq. 2);

$\mathrm{a}_{\mathrm{i}}=\mathrm{F}_{\mathrm{i}} / \mathrm{m}_{\mathrm{i}}$.

The variety of velocities, $v_{i}$, is the integral of acceleration over time. The variation in the position, $r_{i}$, is the integral of velocity over time. Kinetic energy, $\mathrm{K}$, is determined as the velocities of the atoms (Eq. 3) [44, 45];

$\mathrm{K}=1 / 2 \sum_{\mathrm{i}=1}^{\mathrm{N}} \mathrm{m}_{\mathrm{i}} \mathrm{v}_{\mathrm{i}}^{2}$.

The total energy of the system, called the Hamiltonian, is the sum of the kinetic and potential energies (Eq. 4);

$H(r, p)=K(p)+V(r)$

where $r$ is the set of Cartesian coordinates and $p$ is the momenta of the atoms.

The spectral patterns of [cyanidin- $\left(\mathrm{Mg}^{2+}, \mathrm{Ga}^{3+}, \mathrm{Sn}^{2+}, \mathrm{Cr}^{3+}\right.$ and $\left.\mathrm{Fe}^{3+}\right)$ ] metallic cations] are shown in Fig. 4. The control patterns of these complexes were characterized by two peaks at $280 \mathrm{~nm}$ and $520 \mathrm{~nm}$ and their spectral intensities were significantly changed. A significant decrease at $520 \mathrm{~nm}$ and a significant increase at $280 \mathrm{~nm}$, in a sequence of [cyanidin- $\left.\left(\mathrm{Ga}^{3+}>\mathrm{Mg}^{2+}>\mathrm{Cr}^{3+}>\mathrm{Fe}^{3+}\right)\right]$ were observed. 
Fig. 2 Solvation optimized of [anthocyanin-metallic cations of $\mathrm{Mg}^{2+}, \mathrm{Al}^{3+}, \mathrm{Ga}^{3+}, \mathrm{Sn}^{2+}, \mathrm{Cr}^{3+}$ and $\left.\mathrm{Fe}^{3+}\right)$ ] in Iranian Qara Qat fruit with QM/MM model of anthocyanins' family in gas phase (left side) and inside water box periodic box (right side) as solvent model of three stages of m06-HF for the high (H) layer, Pm3MM semi empirical for the medium and Monte Carlo for low layers at $300 \mathrm{~K}$ (a) $\left[\mathrm{Cy}-\mathrm{Mg}^{2+}\right]$

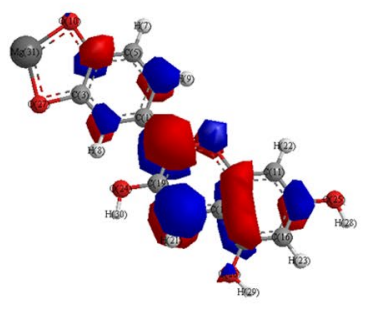

(b) $\left[\mathrm{Cy}-\mathrm{Al}^{3+}\right]$
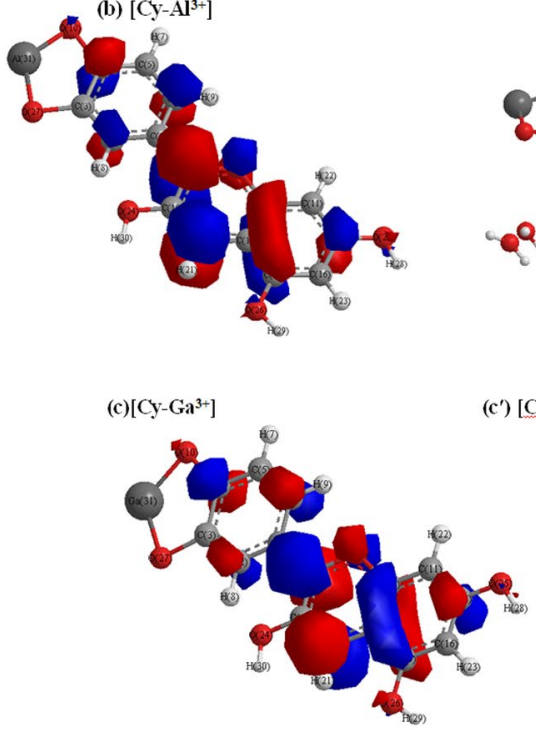

(d) $\left[\mathrm{Cy}-\mathrm{Sn}^{2+}\right]$

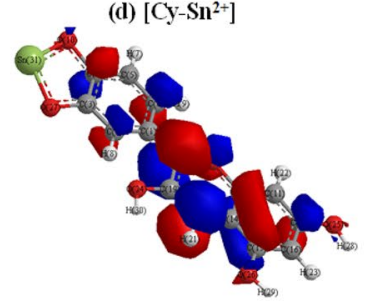

(e) $\left[\mathrm{Cy}-\mathrm{Cr}^{3+}\right]$

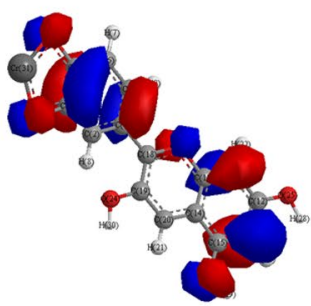

(f) $\left[\mathrm{Cy}-\mathrm{Fe}^{3+}\right]$

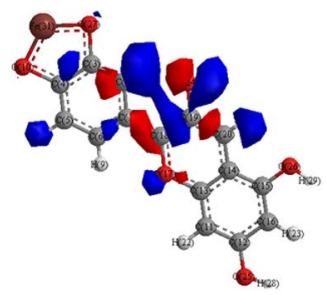

(a') $\left[\mathrm{Cy}-\mathrm{Mg}^{2+}\right], \mathrm{H}_{2} \mathrm{O}$

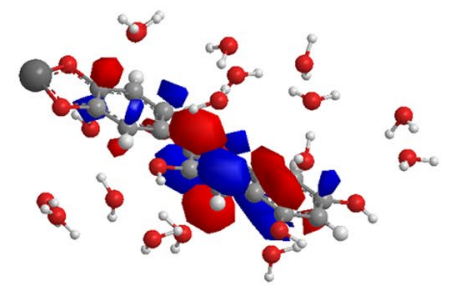

(b') $\left[\mathrm{Cy}-\mathrm{Al}^{3+}\right], \mathrm{H}_{2} \mathrm{O}$

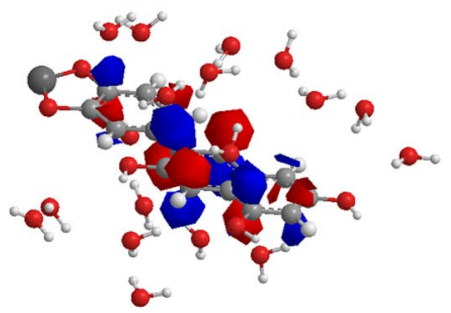

(c) $\left[\mathrm{Cy}-\mathrm{Ga}^{3+}\right], \mathrm{H}_{2} \mathrm{O}$

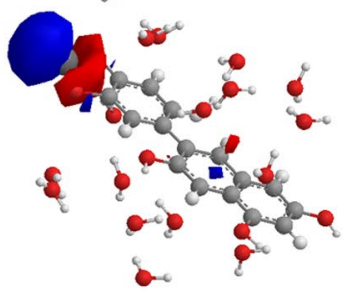

(d') [Cy- $\left.\mathrm{Sn}^{2+}\right], \mathrm{H}_{2} \mathrm{O}$

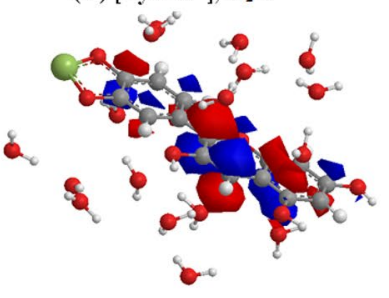

(e') $\left[\mathrm{Cy}-\mathrm{Cr}^{3+}\right], \mathrm{H}_{2} \mathrm{O}$

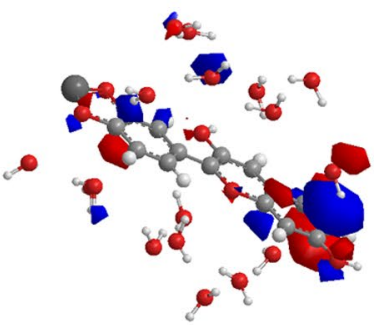

(f') $\left[\mathrm{Cy}-\mathrm{Fe}^{3+}\right], \mathrm{H}_{2} \mathrm{O}$

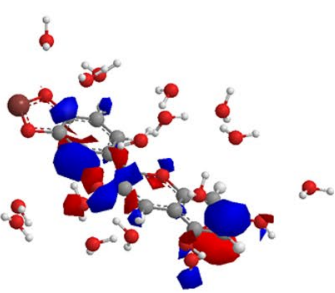




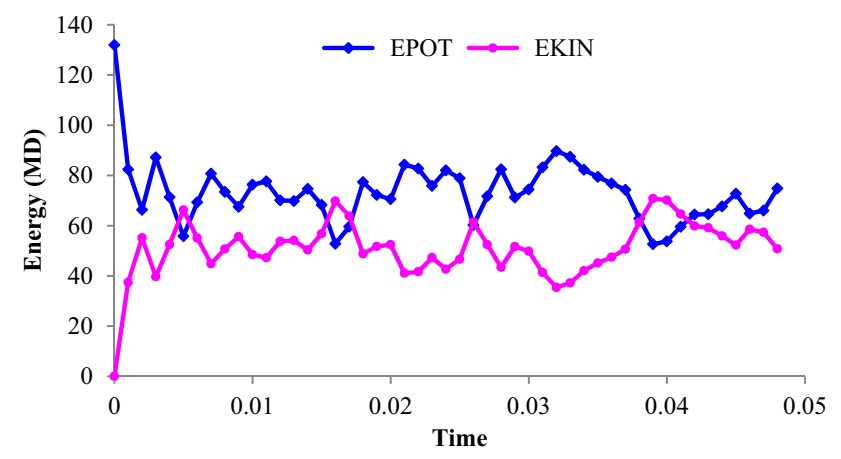

Fig. 3 Optimized energy of anthocyanin-cation metal chelation in Iranian Qara Qat fruit

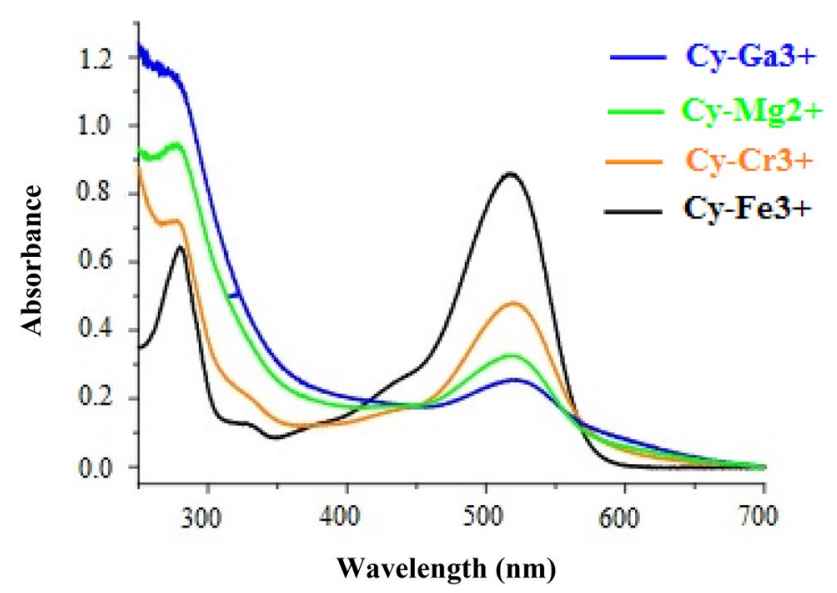

Fig. 4 The effects of metal chelation on the UV-Vis spectral characteristics of cyaniding- $\mathrm{M}^{\mathrm{n}+}\left(\mathrm{M}=\mathrm{Mg}^{2+}, \mathrm{Fe}^{3+}, \mathrm{Al}^{3+}, \mathrm{Ga}^{3+}\right)$ in Iranian Qara Qat fruit

It has been obvious that each site of the complexes including cyanidin- $\left[\mathrm{Mg}^{2+}, \mathrm{Al}^{3+} / \mathrm{Cr}^{3+}, \mathrm{Fe}^{3+}, \mathrm{Ga}^{3+}\right]$ have been minimized by ab-initio method via (DFT), density functional theory, which consists of ECP calculations with theoretical levels of lanl1, lanl 2 basis sets and pseudo key due to the metal elements. Besides, those structures have been estimated via QM/MM complex method using an ONIOM level. In our study, the varieties of theoretical methods are discussed due to comparing density and energies with two approaches of "OPLS" and "AMBER" via Monte Carlo (MC) optimization. Moreover, a hyperchem professional (7.01) program pancake has been used for some extra keywords such as "PM3MM" and "PM6" which is pseudo= $\operatorname{lan} 12$.

The density function method (DFT) with the "van der Waals" densities functional was illustrated due to modeling of solvent compounds interactions. All minimizations of solvent effects were done by Gaussian09 package. The corrected results were calculated using the theoretical levels of "m062x", "m06-L", and "m06" for chelation of cyanidin metallic cation effect. The "m062x", "m06-L" and "m06-HF methods have a suitable correlation in non-bonded calculations between these structures and solvent molecules. The ONIOM theoretical levels have been performed through three levels of high " $\mathrm{H}$ ", medium " $\mathrm{M}$ " and low " $\mathrm{L}$ " calculations which The density function method (DFT) methods were applied for the high " $\mathrm{H}$ " layer and the semi empirical method of "PM6" and "PM3MM" was applied for the medium and finally Monte Carlo (MC) for low layers, respectively.

The Polarizable Continuum Model, "PCM", is the most popular "SCRF" model based on apparent surface charges diffusing to discuss non-electrostatic impacts with scaled point theory $[46,47]$.

Kirkwood developed $[48,49]$ the most common levels of the "SCRF" method of multiple expansions with an algorithm based on the use of a strict multipolar expansion up to the 7th order by Frisch that is currently available at both semi-empirical and ab initio levels of theory.

Onsager [50] and have arranged an intention for various continuum solvation examples of a multiple expansion, "MPE", of the solute charge distribution [51].Then, Wiberg and co-workers improved Onsager-SCRF for the Gaussian program [52].

Solvation is illustrated in terms of a dipole moment with an iterative path of quantum mechanics calculations on the structure. The perspective of Onsager-SCRF was one to directly apply almost all of the computational characteristics of Gaussian program. The dielectric continuum models like the self-consistent reaction field approach are efficient in applying account the long range of solute-solvent electrostatic interactions and the effect of solvent polarization. Another theoretical level is combination of molecular mechanics (MM) solvent molecule with quantum mechanics level (QM) for electronic structure of the solute molecule named " $\mathrm{QM} / \mathrm{MM}$ " which can modify deficiency of the dielectric continuum model $[53,54]$.

Absorbance is a direct measure of how much light is absorbed by our samples in this work. As the absorbance can take on values between 0 (at $100 \%$ Transmittance) and about 2.0 (at 1\% Transmittance); thus large values of absorbance are associated with very little light passing entirely through the sample and small values of absorbance are associated with most of the light passing entirely through the samples. We could imagine two interesting situations. First one, if we pass a beam of light of the appropriate wavelength through a fairly dilute solution, second, we could imagine that the photons will encounter a small number of the absorbing by the metal ions of chemical species such as metallic cations of $\left(\mathrm{Mg}^{2+}, \mathrm{Al}^{3+}, \mathrm{Ga}^{3+}, \mathrm{Sn}^{2+}, \mathrm{Cr}^{3+}\right.$ and $\left.\mathrm{Fe}^{3+}\right)$, so we might expect a high \% transmittance and a low absorbance. Alternatively, if we pass the same beam of light 
through a highly concentrated solution, we could imagine that the photons will encounter a large number of the absorbing chemical species including [anthocyanin-metallic cations of $\mathrm{Mg}^{2+}, \mathrm{Al}^{3+}, \mathrm{Ga}^{3+}, \mathrm{Sn}^{2+}, \mathrm{Cr}^{3+}$ and $\left.\left.\mathrm{Fe}^{3+}\right)\right]$.

In this article, the light goes due to a number of molecules as the system, the anthocyanidin pigments appear the spectrum of molecular transformations with the $\mathrm{pH}$ varieties, and generating variation in colors; (1) (Flavylium cation) $\mathrm{pH}^{\prime} 3$ red, (2) Carbonyl pseudo base ( $\mathrm{pH}=4-5$ colorless), (3) the hydro base $(\mathrm{pH}=6-7$ violet), (4) an-hydro base anion ( $\mathrm{pH}=7-8$ blue), (5) chalcone $\left(\mathrm{pH}^{>} 8 \text { yellow) }\right]^{\prime \prime}$, therefore $\frac{l_{0}}{l_{1}}=\frac{l_{2}}{l_{3}}+\frac{l_{3}}{l_{4}}+\frac{l_{4}}{l_{5}}=n$. This qualitative relationship is defined by a function for light intensity: $I_{i}=I_{0} n^{-i}$ or $I_{i}=10^{-i \log _{n}^{10}}$ which " $i$ " is a number of species in the mechanism. The final expression might be normalized for each system with light path-length $(I): I=I_{0} 10^{-k I}$, which $\mathrm{k}$ is the coefficient depending on concentration, $c$, and the molar absorptivity, $\varepsilon$ : consequently, $\mathrm{k}=\varepsilon \times \mathrm{c}$ (Scheme 4).

A Hyperchem model has been applied for calculation the $\mathrm{pH}$ [Scheme 5] using a box via various dimensions including $\mathrm{N}$ molecules $\mathrm{H}_{3} \mathrm{O}^{+}$. The volume $(\mathrm{V})$ of each box has been yielded by multiple of $\mathrm{V}=a \times b \times c$ and the $\mathrm{pH}$ has been calculated via concentration of $\left[\mathrm{H}^{+}\right]=\mathrm{N} / \mathrm{V}$ with $\mathrm{pH}=-\log \left[\mathrm{H}^{+}\right]$.

\section{Results and discussion}

In this project, three anthocyanin pigments of cyanidin $(C y)$, delphinidin (Dp), and petunidin (Pt) have been estimated using theoretical methods to measure the effect of metal chelation of different plants including factorial excess of metallic cations of $\mathrm{Mg}^{2+}, \mathrm{Al}^{3+}, \mathrm{Ga}^{3+}, \mathrm{Sn}^{2+}, \mathrm{Cr}^{3+}$ and $\mathrm{Fe}^{3+}$ ) in different $\mathrm{pH}$ and evaluated by IR spectroscopy using Gaussian09 in two media of gas and water at $300 \mathrm{~K}$ (Figs. 1, 2).

The thermodynamic properties of $\Delta \mathrm{G}, \Delta \mathrm{H}, \Delta \mathrm{S}$, Electronic Energy and Core-Core Interaction, frequency spectrums, anthocyanin concentration, and $\mathrm{pH}$ determined final color and intensity (Table 2 and Fig. 5a, b) [37, 55]. The difference of $\Delta \mathrm{H}_{\mathrm{R}}$ among [anthocyanin-metallic cations of $\left(\mathrm{Mg}^{2+}, \mathrm{Al}^{3+}\right.$, $\mathrm{Ga}^{3+}, \mathrm{Sn}^{2+}, \mathrm{Cr}^{3+}$ and $\left.\mathrm{Fe}^{3+}\right)$ ] cluster chelation in Iranian Qara Qat fruit (Fig. 5b) has been unraveled due to double bonds and carbonyl groups through the chelation of (B)-ring for $\mathrm{Cy}, \mathrm{Dp}$ and $\mathrm{Pt}$ anthocyanins in two media of gas and water.

They have been illustrated the stabilities and color of [anthocyanin-metallic cations of $\mathrm{Mg}^{2+}, \mathrm{Al}^{3+}, \mathrm{Ga}^{3+}, \mathrm{Sn}^{2+}$, $\mathrm{Cr}^{3+}$ and $\left.\mathrm{Fe}^{3+}\right)$ ] cluster chelation of $\mathrm{Cy}, \mathrm{Dp}$, and Pt pigments in Iranian Qara Qat fruit in a weak acidic condition (Figs. 1, 2).

The highest chelate stability with different ACNs indicates that $\mathrm{ACN}$-metal chelation can produce a variety range of colors under acidic $\mathrm{pH}$ with efficiency for food consume. The results of $\Delta \mathrm{H}_{\mathrm{R}}$ for formation of

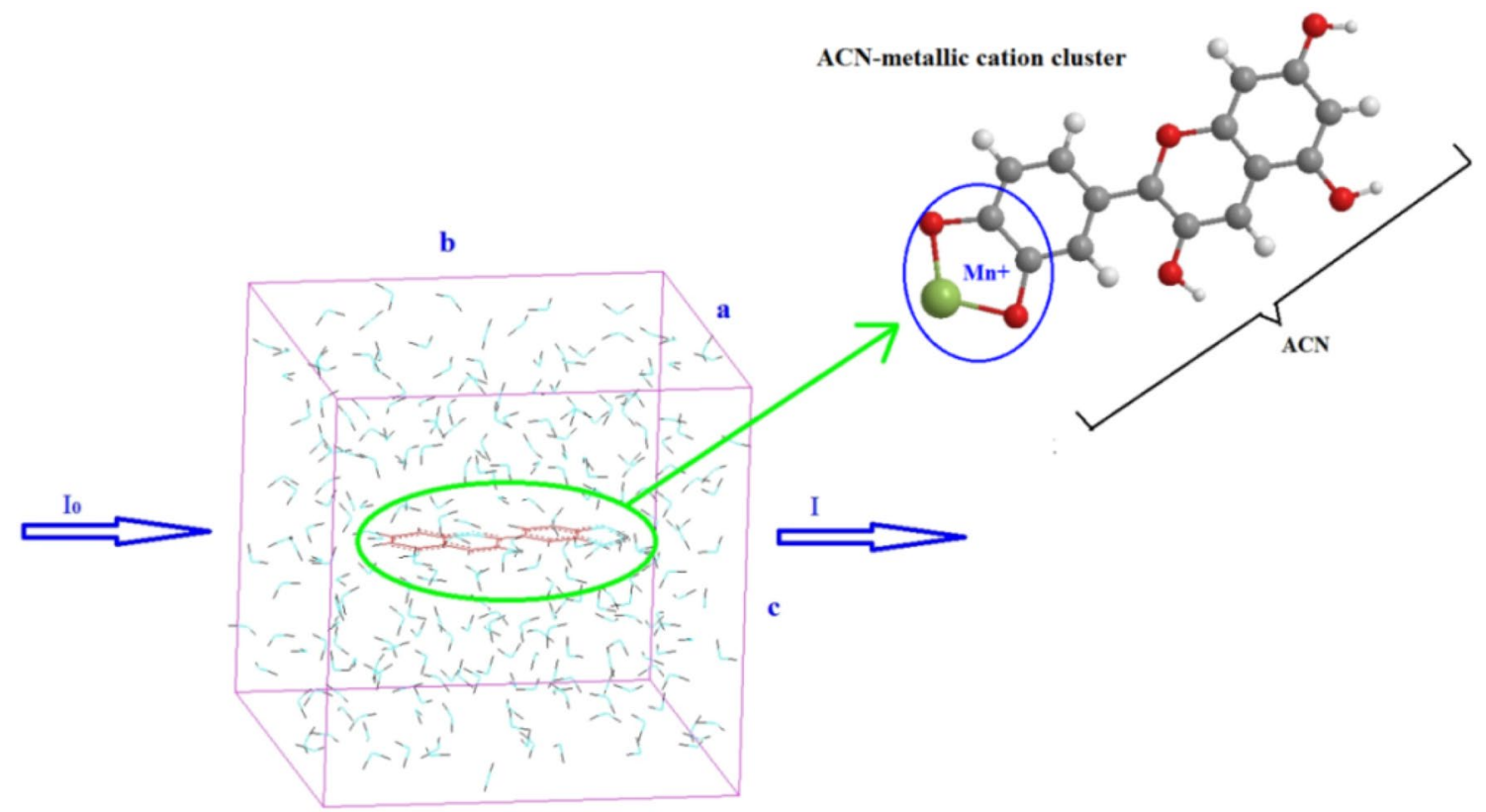

Scheme 4 The relation of light intensity in the Beer Lambert law with concentration aspect of metal ion chelation of anthocyanin's family like anthocyanin- $\mathrm{M}^{\mathrm{n}+}$, in water in Iranian Qara Qat fruit 
Scheme 5 The 112 number of $\mathrm{H}_{3} \mathrm{O}^{+}$around the $\mathrm{Cy}-\mathrm{Sn}$ in a box with dimension $\mathrm{a}=15$, $b=15$ and $c=15$ angstrom for calculation the concentration of $\left[\mathrm{H}^{+}\right]$and also estimating of the related $\mathrm{pH}$

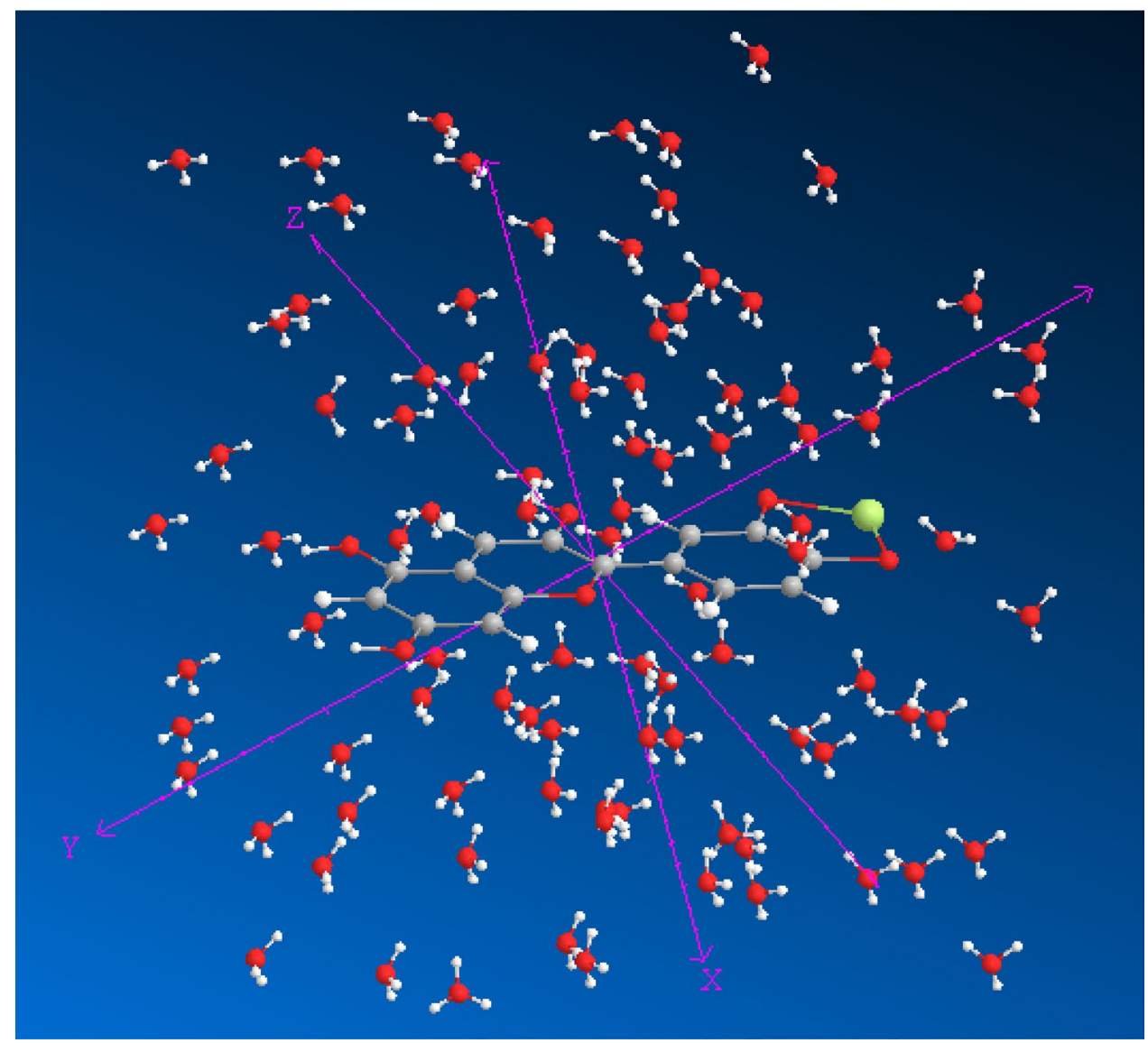

[anthocyanin-metallic cations of $\mathrm{Mg}^{2+}, \mathrm{Al}^{3+}, \mathrm{Ga}^{3+}, \mathrm{Sn}^{2+}$, $\mathrm{Cr}^{3+}$ and $\left.\mathrm{Fe}^{3+}\right)$ ] cluster chelation have been extracted by Fig. $5 b$ and data of Tables 2 and 3.

Recently, Beer Lambert law has been used for optimized compounds of [anthocyanin-metallic cations of (magnesium, aluminum, gallium, tin, chrome and iron)] cluster chelation in Iranian Qara Qat fruit to demonstrate the absorbance of assigned molecules toward showing the stabilization and a range of color due to their electronic structures in $\mathrm{H}_{2} \mathrm{O}$ medium with different concentrations of $\mathrm{H}^{+}$[55-57]. The absorbance (A) of the [anthocyanin-metallic cations of (magnesium, aluminum, gallium, tin, chrome and iron)] of cyanidin, delphinidin, and petunidin colorful pigments in Iranian Qara Qat fruit in $\mathrm{H}_{2} \mathrm{O}$ periodic box of a simulated model has been calculated through the Beer Lambert law which directly depends on concentration (c/mol/L) of $\mathrm{H}^{+}$. The results have been shown in [55-57] based on basic equations of $A=\log _{10}\left(I_{0} / I\right)=\varepsilon \mid c$, where $A$ is the absorbance; I, intensity of light; $\varepsilon$, molar absorptivity coefficient and c, concentration of solution. Basically, the increase in absorbance continued to rise with increasing and decreasing of frequency (F) for anthocyanin-metal cation chelation of cyanidin- $\mathrm{Al}^{3+}$ and petunidin- $\mathrm{Al}^{3+}$ in higher $\mathrm{pH}$, respectively.
These decreases in absorbance could be related to decreased solubility of the anthocyanin- $\mathrm{M}^{\mathrm{n}+}$-cluster chelation which is resulted in precipitation of some complexes. In neutral or alkaline $\mathrm{pH}$, hyper-chromic effects were found to be highest with much lower $\mathrm{M}^{\mathrm{n}+}$ levels; they were largest in higher $\mathrm{pH}$ with $\mathrm{M}^{\mathrm{n}+}$ and [anthocyanin], respectively, and were pursued by absorbance decreases. The large increases in absorbance could be treated to convert as the colorless forms of ACN to those which absorb and reflect visible light as well as the $\mathrm{M}^{\mathrm{n}+}$ induced linked to anthocyanin compounds.

So, it has been shown the Changes of absorbance (A) versus concentration (c) through Beer Lambert law for [cyaniding-metallic cations of $\mathrm{Mg}^{2+}, \mathrm{Al}^{3+}, \mathrm{Ga}^{3+}, \mathrm{Sn}^{2+}, \mathrm{Cr}^{3+}$ and $\mathrm{Fe}^{3+}$ ]chelation and [petunidin-metallic cations of $\mathrm{Mg}^{2+}, \mathrm{Al}^{3+}, \mathrm{Ga}^{3+}, \mathrm{Sn}^{2+}, \mathrm{Cr}^{3+}$ and $\left.\left.\mathrm{Fe}^{3+}\right)\right]$ cluster chelation in the weak acidic media by different concentrations of $\mathrm{H}^{+}$ at $300 \mathrm{~K}$ [55-57].

There is a high tendency to the absorbance of Cy, Dp and $\mathrm{Pt}$ with $\mathrm{Mg}^{2+}$ added, but the changes were of small magnitude by playing a role in organizing ACN into supramolecular assembly similar to the role of $\mathrm{Mg}^{2+}$, which plays in metalloanthocyanins formation [36].

$\mathrm{Mg}^{2+}$ is the only divalent metal cation used in this work which is a crucial $\mathrm{M}^{\mathrm{n}+}$ to life system and usually linked to 
Table 2 Thermodynamic properties of $\mathrm{Mg}^{2+}, \mathrm{Al}^{3+}, \mathrm{Ga}^{3+}$, $\mathrm{Sn}^{2+}, \mathrm{Cr}^{3+}$ and $\left.\mathrm{Fe}^{3+}\right)$ metallic cation chelation for cyanidin, delphinidin, petunidin pigments in two media of gas $(\mathrm{g})$ and water (w) at $300 \mathrm{~K}$, calculated by $\mathrm{m} 062 \mathrm{x} / \mathrm{cc}-\mathrm{pvdz}$ pseudo $=\operatorname{lanl} 2$

\begin{tabular}{|c|c|c|c|c|c|}
\hline $\begin{array}{l}\text { Pigment- } \\
\text { metal chela- } \\
\text { tion }\end{array}$ & $\Delta \mathrm{G}(\mathrm{kcal} / \mathrm{mol})$ & $\Delta \mathrm{H}(\mathrm{kcal} / \mathrm{mol})$ & $\Delta \mathrm{S}(\mathrm{kcal} / \mathrm{K} \cdot \mathrm{mol})$ & $\mathrm{E}_{\text {electronic }}(\mathrm{kcal} / \mathrm{mol})$ & $\mathrm{E}_{\text {core-core }}(\mathrm{kcal} / \mathrm{mol})$ \\
\hline $\mathrm{Cy}-\mathrm{Mg}^{2+}(\mathrm{g})$ & $-8.52 \times 10^{4}$ & $-4.57 \times 10$ & $2.84 \times 10^{2}$ & $-5.33 \times 10^{5}$ & $4.47 \times 10^{5}$ \\
\hline $\mathrm{Cy}-\mathrm{Mg}^{2+}(\mathrm{w})$ & $-2.27 \times 10^{5}$ & $-1.08 \times 10^{3}$ & $7.55 \times 10^{2}$ & $-2.21 \times 10^{6}$ & $1.98 \times 10^{6}$ \\
\hline $\mathrm{Dp}-\mathrm{Mg}^{2+}(\mathrm{g})$ & $-9.20 \times 10^{4}$ & $-8.49 \times 10$ & $3.06 \times 10^{2}$ & $-5.83 \times 10^{5}$ & $4.91 \times 10^{5}$ \\
\hline $\mathrm{Dp}-\mathrm{Mg}^{2+}(\mathrm{w})$ & $-2.19 \times 10^{5}$ & $-1.03 \times 10^{3}$ & $7.28 \times 10^{2}$ & $-2.05 \times 10^{6}$ & $1.83 \times 10^{6}$ \\
\hline $\mathrm{Pt}_{-} \mathrm{Mg}^{2+}(\mathrm{g})$ & $-9.54 \times 10^{4}$ & $-7.12 \times 10$ & $3.18 \times 10^{2}$ & $-6.33 \times 10^{5}$ & $5.38 \times 10^{5}$ \\
\hline Pt-Mg ${ }^{2+}(w)$ & $-2.15 \times 10^{5}$ & $-9.70 \times 10^{2}$ & $7.14 \times 10^{2}$ & $-2.05 \times 10^{6}$ & $1.83 \times 10^{6}$ \\
\hline $\mathrm{Cy}-\mathrm{Al}^{3+}(\mathrm{g})$ & $-8.58 \times 10^{4}$ & $-8.33 \times 10$ & $2.86 \times 10^{2}$ & $-5.40 \times 10^{5}$ & $4.54 \times 10^{5}$ \\
\hline $\mathrm{Cy}-\mathrm{Al}^{3+}(\mathrm{w})$ & $-2.28 \times 10^{5}$ & $-1.05 \times 10^{3}$ & $7.57 \times 10^{2}$ & $-2.22 \times 10^{6}$ & $1.99 \times 10^{6}$ \\
\hline $\mathrm{Dp}-\mathrm{Al}^{3+}(\mathrm{g})$ & $-9.26 \times 10^{4}$ & $-1.25 \times 10^{2}$ & $3.08 \times 10^{2}$ & $-5.91 \times 10^{5}$ & $4.98 \times 10^{5}$ \\
\hline $\mathrm{Dp}-\mathrm{Al}^{+3}(\mathrm{w})$ & $-2.20 \times 10^{5}$ & $-1.00 \times 10^{3}$ & $7.30 \times 10^{2}$ & $-2.07 \times 10^{6}$ & $1.85 \times 10^{6}$ \\
\hline $\mathrm{Pt}_{-\mathrm{Al}}^{+3+}(\mathrm{g})$ & $-9.60 \times 10^{4}$ & $-1.12 \times 10^{2}$ & $3.20 \times 10^{2}$ & $-6.41 \times 10^{5}$ & $5.45 \times 10^{5}$ \\
\hline $\mathrm{Pt}^{-\mathrm{Al}^{3+}}(\mathrm{w})$ & $-2.16 \times 10^{5}$ & $-9.40 \times 10^{2}$ & $7.16 \times 10^{2}$ & $-2.07 \times 10^{6}$ & $1.85 \times 10^{6}$ \\
\hline $\mathrm{Cy}-\mathrm{Ga}^{3+}(\mathrm{g})$ & $-8.60 \times 10^{4}$ & $-1.63 \times 10$ & $2.86 \times 10^{2}$ & $-5.41 \times 10^{5}$ & $4.55 \times 10^{5}$ \\
\hline $\mathrm{Cy}-\mathrm{Ga}^{3+}(\mathrm{w})$ & $-2.28 \times 10^{5}$ & $-1.05 \times 10^{3}$ & $7.57 \times 10^{2}$ & $-2.22 \times 10^{6}$ & $1.99 \times 10^{6}$ \\
\hline $\mathrm{Dp}-\mathrm{Ga}^{3+}(\mathrm{g})$ & $-9.28 \times 10^{4}$ & $-5.53 \times 10$ & $3.09 \times 10^{2}$ & $-5.92 \times 10^{5}$ & $4.99 \times 10^{5}$ \\
\hline $\mathrm{Dp}-\mathrm{Ga}^{3+}(\mathrm{w})$ & $-2.20 \times 10^{5}$ & $-1.02 \times 10^{3}$ & $7.30 \times 10^{2}$ & $-2.07 \times 10^{6}$ & $1.85 \times 10^{6}$ \\
\hline $\mathrm{Pt}_{-G^{3+}}(\mathrm{g})$ & $-9.63 \times 10^{4}$ & $-9.61 \times 10$ & $3.20 \times 10^{2}$ & $-6.42 \times 10^{5}$ & $5.46 \times 10^{5}$ \\
\hline $\mathrm{Pt}_{-\mathrm{Ga}^{3+}}(\mathrm{w})$ & $-2.23 \times 10^{5}$ & $-1.02 \times 10^{3}$ & $7.42 \times 10^{2}$ & $-2.19 \times 10^{6}$ & $1.96 \times 10^{6}$ \\
\hline $\mathrm{Cy}-\mathrm{Sn}^{2+}(\mathrm{g})$ & $-8.66 \times 10^{4}$ & $-8.36 \times 10$ & $2.88 \times 10^{2}$ & $-5.47 \times 10^{5}$ & $4.61 \times 10^{5}$ \\
\hline $\mathrm{Cy}-\mathrm{Sn}^{2+}(\mathrm{w})$ & $-2.29 \times 10^{5}$ & $-1.07 \times 10^{3}$ & $7.59 \times 10^{2}$ & $-2.24 \times 10^{6}$ & $2.01 \times 10^{6}$ \\
\hline $\mathrm{Dp}-\mathrm{Sn}^{2+}(\mathrm{g})$ & $-9.33 \times 10^{4}$ & $-8.29 \times 10$ & $3.11 \times 10^{2}$ & $5.05 \times 10^{5}$ & $-5.99 \times 10^{5}$ \\
\hline $\mathrm{Dp}-\mathrm{Sn}^{2+}(\mathrm{w})$ & $-2.21 \times 10^{5}$ & $-1.02 \times 10^{3}$ & $7.32 \times 10^{2}$ & $-2.08 \times 10^{6}$ & $1.86 \times 10^{6}$ \\
\hline $\mathrm{Pt}-\mathrm{Sn}^{2+}(\mathrm{g})$ & $-9.67 \times 10^{4}$ & $-5.71 \times 10$ & $3.22 \times 10^{2}$ & $-6.49 \times 10^{5}$ & $5.53 \times 10^{5}$ \\
\hline $\mathrm{Pt}-\mathrm{Sn}^{2+}(\mathrm{w})$ & $-9.67 \times 10^{4}$ & $-5.71 \times 10$ & $3.22 \times 10^{2}$ & $-6.49 \times 10^{5}$ & $5.53 \times 10^{5}$ \\
\hline $\mathrm{Cy}-\mathrm{Cr}^{3+}(\mathrm{g})$ & $-9.03 \times 10^{4}$ & $-0.91 \times 10$ & $3.01 \times 10^{2}$ & $-5.68 \times 10^{5}$ & $4.77 \times 10^{5}$ \\
\hline $\mathrm{Cy}-\mathrm{Cr}^{3+}(w)$ & $-2.33 \times 10^{5}$ & $-1.06 \times 10^{3}$ & $7.72 \times 10^{2}$ & $-2.27 \times 10^{6}$ & $2.04 \times 10^{6}$ \\
\hline $\mathrm{Dp}-\mathrm{Cr}^{3+}(\mathrm{g})$ & $-9.72 \times 10^{4}$ & $-1.14 \times 10^{2}$ & $3.23 \times 10^{2}$ & $-6.20 \times 10^{5}$ & $5.23 \times 10^{5}$ \\
\hline $\mathrm{Dp}-\mathrm{Cr}^{3+}(\mathrm{w})$ & $-2.24 \times 10^{5}$ & $-1.02 \times 10^{3}$ & $7.45 \times 10^{2}$ & $-2.12 \times 10^{6}$ & $1.90 \times 10^{6}$ \\
\hline $\mathrm{Pt}-\mathrm{Cr}^{3+}(\mathrm{g})$ & $-1.00 \times 10^{4}$ & $-7.83 \times 10$ & $3.35 \times 10^{2}$ & $-6.71 \times 10^{5}$ & $5.71 \times 10^{5}$ \\
\hline $\mathrm{Pt}-\mathrm{Cr}^{3+}(\mathrm{w})$ & $-1.90 \times 10^{5}$ & $-7.10 \times 10^{2}$ & $6.32 \times 10^{2}$ & $-1.72 \times 10^{6}$ & $1.53 \times 10^{6}$ \\
\hline $\mathrm{Cy}-\mathrm{Fe}^{3+}(\mathrm{g})$ & $-9.68 \times 10^{4}$ & $-1.34 \times 10^{2}$ & $3.22 \times 10^{2}$ & $-5.88 \times 10^{5}$ & $4.92 \times 10^{5}$ \\
\hline $\mathrm{Cy}-\mathrm{Fe}^{3+}(w)$ & $-2.24 \times 10^{5}$ & $-1.02 \times 10^{3}$ & $7.44 \times 10^{2}$ & $-2.10 \times 10^{6}$ & $1.88 \times 10^{6}$ \\
\hline $\mathrm{Dp}-\mathrm{Fe}^{3+}(\mathrm{g})$ & $-1.03 \times 10^{4}$ & $-7.85 \times 10$ & $3.45 \times 10^{2}$ & $-6.41 \times 10^{5}$ & $5.38 \times 10^{5}$ \\
\hline $\mathrm{Dp}-\mathrm{Fe}^{3+}(\mathrm{w})$ & $-2.31 \times 10^{5}$ & $-1.09 \times 10^{3}$ & $7.66 \times 10^{2}$ & $-2.16 \times 10^{6}$ & $1.92 \times 10^{6}$ \\
\hline $\mathrm{Pt}-\mathrm{Fe}^{3+}(\mathrm{g})$ & $-1.07 \times 10^{4}$ & $-1.60 \times 10^{2}$ & $3.56 \times 10^{2}$ & $-6.93 \times 10^{5}$ & $5.86 \times 10^{5}$ \\
\hline $\mathrm{Pt}^{-\mathrm{Fe}^{3+}}(\mathrm{w})$ & $-1.52 \times 10^{5}$ & $-4.70 \times 10^{2}$ & $5.05 \times 10^{2}$ & $-1.19 \times 10^{6}$ & $1.04 \times 10^{6}$ \\
\hline
\end{tabular}

ACN in plant systems lacking any electrons in d orbitals, and it is able to produce some metalloanthocyanins with the unfilled $\mathrm{d}$ or f orbitals [57]. $\mathrm{Mg}^{2+}$ was found to do function in the stereo chemical configurations of cyanidin, delphinidin and petunidin anthocyanins (Scheme 2, Figs. 1, 2). For discovering the impacts of $\mathrm{Al}^{3+}$ salt on food origin, anthocyanin was measured with the goal to better understanding blue color development of metallo-anthocyanin.

In calculations, $\mathrm{Al}^{3+}$ was identified to displace $\mathrm{Mg}^{2+}$ in anthocyanin- $\mathrm{Mg}^{2+}$ complexes, Cy based, and produces more stable complexes [55-57]. This $\mathrm{M}^{\mathrm{n}+}$ has also even been estimated as a key to evaluate cyanidin, delphinidin and petunidin in anthocyanin extracts from edible sources [55-57]. Similar to $\mathrm{Mg}^{2+}, \mathrm{Al}^{3+}$ also lacks electrons in $d$ orbitals but is trivalent when ionized.

In all $\mathrm{pH}$, the frequency and dipole moment of anthocyanin-chelation were found to be significantly different with each metal treatment metallic cations of $\left(\mathrm{Mg}^{2+}, \mathrm{Al}^{3+}, \mathrm{Ga}^{3+}, \mathrm{Sn}^{2+}, \mathrm{Cr}^{3+}\right.$ and $\left.\mathrm{Fe}^{3+}\right)$ in Iranian Qara Qat fruit (Table 4).It has been seen that by increasing the $\mathrm{pH}$, the frequency of [anthocyanin-metallic cations of $\left(\mathrm{Mg}^{2+}, \mathrm{Al}^{3+}, \mathrm{Ga}^{3+}, \mathrm{Sn}^{2+}, \mathrm{Cr}^{3+}\right.$ and $\left.\left.\mathrm{Fe}^{3+}\right)\right]$ cluster chelation in Iranian Qara Qat fruit increases between $\mathrm{pH} \approx 1.1-1.5$ (Table 4, Fig. 6a, b). 
Fig. 5 a Changes of Gibbs free energy $(\mathrm{kcal} / \mathrm{mol})$ of $\left[\mathrm{ACN}-\mathrm{Mg}^{2+} / \mathrm{Al}^{3+} / \mathrm{Ga}^{3+} / \mathrm{Sn}^{2+} /\right.$ $\mathrm{Cr}^{3+} / \mathrm{Fe}^{3+}$ ] cluster chelation of Iranian Qara Qat fruit in two media of gas $(\mathrm{g})$ and water (w) at $300 \mathrm{~K}, \mathbf{b}$ Changes of enthalpy of reaction $\left(\Delta \mathrm{H}_{\mathrm{R}}\right)$ for formation of $\left[\mathrm{ACN}-\mathrm{Mg}^{2+} / \mathrm{Al}^{3+} /\right.$ $\left.\mathrm{Ga}^{3+} / \mathrm{Sn}^{2+} / \mathrm{Cr}^{3+} / \mathrm{Fe}^{3+}\right]$ clusters in water medium

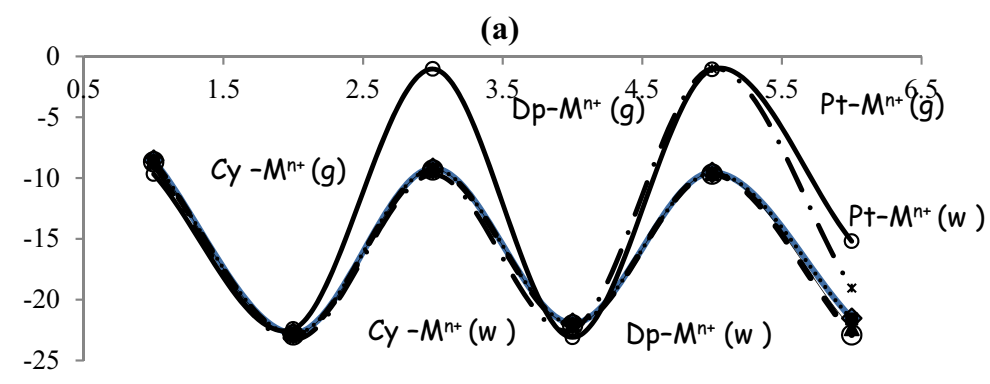

$\diamond \Delta \mathrm{GAC}-\mathrm{Mg} 2+\quad \cdots \cdot \cdots \Delta \mathrm{GAC}-\mathrm{Al} 3+\quad \longrightarrow$ GAC-Ga3+

(b)

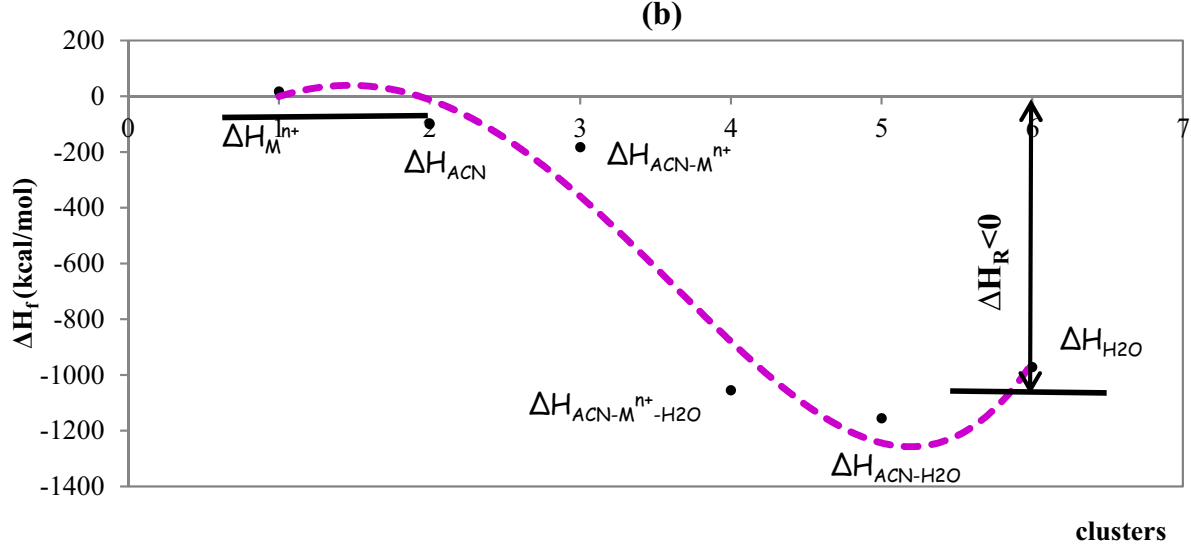

Table 3 The difference of $\Delta \mathrm{H}_{\mathrm{R}}$ through formation of [anthocyanin-metallic cations of (magnesium, aluminum, gallium, tin, chrome and iron)] cluster chelation in Iranian Qara Qat fruit

\begin{tabular}{|c|c|c|c|c|c|c|c|c|c|c|c|}
\hline \multicolumn{12}{|c|}{$\Delta \mathrm{H}_{\mathrm{R}}\left(\mathrm{ACN}-\mathrm{M}^{\mathrm{n}+}-\mathrm{H} 2 \mathrm{O}\right)(\mathrm{kcal} / \mathrm{mol})$} \\
\hline Cy-Mg ${ }^{2+}$ & 217.96 & $\mathrm{Cy}-\mathrm{Al}^{3+}$ & 283.95 & $\mathrm{Cy}-\mathrm{Ga}^{3+}$ & 288.58 & $\mathrm{Cy}-\mathrm{Sn}^{2+}$ & 262.94 & $\mathrm{Cy}-\mathrm{Cr}^{3+}$ & 199.19 & $\mathrm{Cy}-\mathrm{Fe}^{3+}$ & 367.63 \\
\hline $\mathrm{Dp}-\mathrm{Mg}^{2+}$ & 382.21 & Dp-Al ${ }^{3+}$ & 453.46 & $\mathrm{Dp}-\mathrm{Ga}^{3+}$ & 360.07 & $\mathrm{Dp}-\mathrm{Sn}^{2+}$ & 387.29 & $\mathrm{Dp}-\mathrm{Cr}^{3+}$ & 423.68 & $\mathrm{Dp}-\mathrm{Fe}^{3+}$ & 319.20 \\
\hline Pt-Mg ${ }^{2+}$ & 307.33 & Pt-Al ${ }^{3+}$ & 378.33 & Pt-Ga ${ }^{3+}$ & 278.95 & $\mathrm{Pt}-\mathrm{Sn}^{2+}$ & 941.16 & Pt-Cr ${ }^{3+}$ & 575.31 & $\mathrm{Pt}-\mathrm{Fe}^{3+}$ & 896.93 \\
\hline
\end{tabular}

The maximum frequency of $\mathrm{Al}^{3+}$ treated acylated cyanidin was greater indicating the development of bluer colors, especially in higher $\mathrm{pH}$ with effects on their visible light absorbance (Fig. 6a, b).

Although we have little information about the interaction of anthocyanin with $\mathrm{Cr}^{3+}$, it is trivalent $\mathrm{M}^{\mathrm{n}+}$ having electrons in d orbitals, where addition of $\mathrm{Cr}^{3+}$ to the ACN of this study was also found to induce frequency and absorbance of spectra. In all $\mathrm{pH}$, the mean frequency of the anthocyanin of both sources was achieved to be various from one another with each metal cation.

Similar trends occurred with $\mathrm{Cr}^{3+}$, where the $\mathrm{F}_{\text {max }}$ of chelated cyanidin and delphinidin were greater while it has been indicated the maximum $\mathrm{F}$ of the anthocyanin with $\mathrm{Cr}^{3+}$ compared to $\mathrm{Al}^{3+}$ in chelation by cyanidin and petunidin.

Like $\mathrm{Al}^{3+}$, the impacts of $\mathrm{Fe}^{3+}$ chelated to anthocyanin were investigated to be better characterized to generate some anthocyanin based blue colorations. $\mathrm{Fe}^{3+}$ is known to play an important role in many of the known pigment macromolecules [36].

Those metalloanthocyanins with cyanidin chromophores need $\mathrm{Fe}^{3+}$ to generate blue hues, but those based on delphinidin chromophores can produce blue colors. So, it has been seen anthocyanin formed bonds with $\mathrm{Fe}^{3+}$ producing the highest shifted of frequency and absorbance compared to other metalloanthocyanins (Fig. 6a, b).

As it has been seen in Table 4, the physical properties of high frequency and dipole moment for anthocyaninmetal cation chelation of cyanidin- $\mathrm{Al}^{3+}$, delphinidin- $\mathrm{Al}^{3+}$, and petunidin- $\mathrm{Al}^{3+}$ have been calculated in weak acidic media extracted from the infrared computational method which has shown a high deviation of absorbance for $\left[\mathrm{Al}^{3+}\right.$-chelation] of Dp pigment [55-57].

The frequency achieved of IR vibrational spectra has shown that the normal mode of the active sites due to 
Table 4 Calculated dipole moment (D) (Debyes) and Frequency (F) $(1 / \mathrm{cm})$ of anthocyanin-metal chelation of cyanidin, delphinidin and petunidin in various $\mathrm{pH}$ using IR spectra

\begin{tabular}{|c|c|c|c|c|c|c|c|c|c|c|c|c|}
\hline \multirow[t]{2}{*}{$\overline{\mathrm{pH}}$} & \multicolumn{2}{|c|}{$\mathrm{Cy}-\mathrm{Mg}^{2+}$} & \multicolumn{2}{|l|}{$\mathrm{Cy}-\mathrm{Al}^{3+}$} & \multicolumn{2}{|l|}{$\mathrm{Cy}-\mathrm{Ga}^{3+}$} & \multicolumn{2}{|c|}{$\mathrm{Cy}-\mathrm{Sn}^{2+}$} & \multicolumn{2}{|l|}{$\mathrm{Cy}-\mathrm{Cr}^{3+}$} & \multicolumn{2}{|l|}{$\mathrm{Cy}-\mathrm{Fe}^{3+}$} \\
\hline & $\mathrm{D}$ & $\mathrm{F}$ & $\mathrm{D}$ & $F$ & D & $\mathrm{F}$ & $\mathrm{D}$ & $\mathrm{F}$ & D & $F$ & D & $F$ \\
\hline .17 & 3.047 & 3922.7 & 18.655 & 3924.86 & 18.655 & 3924.86 & 4.027 & 3923.82 & 9.94 & 3926.3 & 7.384 & 3924.71 \\
\hline 1.30 & 3.24 & 3927.39 & 16.739 & 3925.22 & 16.739 & 3925.22 & 3.104 & 3924.09 & 8.391 & 3931.09 & 5.914 & 3926.28 \\
\hline 1.39 & 1.532 & 3927.39 & 16.351 & 3926.23 & 16.351 & 3926.23 & 6.931 & 3926.32 & 10.313 & 3926.2 & 7.149 & 3926.28 \\
\hline 1.47 & 5.276 & 4014.5 & 13.82 & 4008.35 & 13.82 & 4008.35 & 3.081 & 3927.35 & 8.592 & 3926.21 & 4.695 & 3928.35 \\
\hline 1.54 & 3.911 & 4012.12 & 6.687 & 4007.68 & 6.687 & 4007.68 & 7.005 & 4012.07 & 9.588 & 4009.28 & 6.471 & 4012.01 \\
\hline \multirow[t]{2}{*}{$\mathrm{pH}$} & \multicolumn{2}{|c|}{$\mathrm{Dp}-\mathrm{Mg}^{2+}$} & \multicolumn{2}{|l|}{$\mathrm{Dp}-\mathrm{Al} \mathrm{l}^{3+}$} & \multicolumn{2}{|l|}{$\mathrm{Dp}-\mathrm{Ga}^{3+}$} & \multicolumn{2}{|c|}{$\mathrm{Dp}-\mathrm{Sn}^{2+}$} & \multicolumn{2}{|l|}{$\mathrm{Dp}-\mathrm{Cr}^{3+}$} & \multicolumn{2}{|l|}{$\mathrm{Dp}-\mathrm{Fe}^{3+}$} \\
\hline & $D$ & $\mathrm{~F}$ & $D$ & $F$ & D & $\mathrm{F}$ & D & $\mathrm{F}$ & D & $F$ & $D$ & $F$ \\
\hline 1.17 & 6.715 & 3926.53 & 1617.192 & 3925.8 & 18.783 & 3925.41 & 4.656 & 3923.57 & 9.042 & 3933.41 & 7.903 & 3767.49 \\
\hline 1.30 & 3.676 & 3929.42 & 1745.149 & 3929.67 & 14.939 & 3927.6 & 3.513 & 3924.01 & 9.042 & 3933.41 & 1907.476 & 3945.54 \\
\hline 1.39 & 22.597 & 5816.27 & 16.102 & 3929.62 & 12.995 & 3927.92 & 4.200 & 3925.99 & 6.406 & 3935.24 & 6.87 & 3928.67 \\
\hline 1.47 & 4.913 & 3930.14 & 17.007 & 4015.05 & 2293.994 & 4040.77 & 2.271 & 4019.09 & 7.383 & 4017.84 & 5.545 & 4018.25 \\
\hline 1.54 & 3.754 & 4018.29 & 16.865 & 4012.9 & 13.142 & 4014.13 & 3.899 & 4016.72 & 9.034 & 4015.4 & 6.379 & 4016.15 \\
\hline \multirow[t]{2}{*}{$\overline{\mathrm{pH}}$} & \multicolumn{2}{|l|}{ Pt-Mg ${ }^{2+}$} & \multicolumn{2}{|l|}{$\mathrm{Pt}^{-\mathrm{Al}^{3+}}$} & \multicolumn{2}{|l|}{$\mathrm{Pt}-\mathrm{Ga}^{3+}$} & \multicolumn{2}{|c|}{$\mathrm{Pt}-\mathrm{Sn}^{2+}$} & \multicolumn{2}{|l|}{$\mathrm{Pt}-\mathrm{Cr}^{3+}$} & \multicolumn{2}{|l|}{$\mathrm{Pt}-\mathrm{Fe}^{3+}$} \\
\hline & $D$ & $\mathrm{~F}$ & $D$ & $\mathrm{~F}$ & $D$ & $\mathrm{~F}$ & $D$ & $\mathrm{~F}$ & $D$ & $\mathrm{~F}$ & $D$ & $F$ \\
\hline 1.17 & 8.2 & 3925.49 & 22.838 & 3764.23 & 17.776 & 3926.05 & 5.342 & 3924.10 & 26.675 & 3767.37 & 8.2 & 3925.49 \\
\hline 1.30 & 7.887 & 3925.48 & 1.2214 & 3930.1 & 16.375 & 3925.9 & 4.784 & 3924.54 & 9.775 & 3926.38 & 7.887 & 3925.48 \\
\hline 1.39 & 6.593 & 3938.03 & 1935.273 & 7744.65 & 15.786 & 3936.28 & 4.213 & 3925.14 & 9.343 & 3944.92 & 6.593 & 3938.03 \\
\hline 1.47 & 5.341 & 3941.18 & 16.276 & 3953.97 & 2473.38 & 3935.38 & 7.455 & 3925.49 & 6.893 & 3940.57 & 5.341 & 3941.18 \\
\hline 1.54 & 6.517 & 3940.83 & 15.925 & 4013.69 & 12.817 & 4013.77 & 4.721 & 3925.73 & 6.207 & 3943.45 & 6.517 & 3940.83 \\
\hline
\end{tabular}
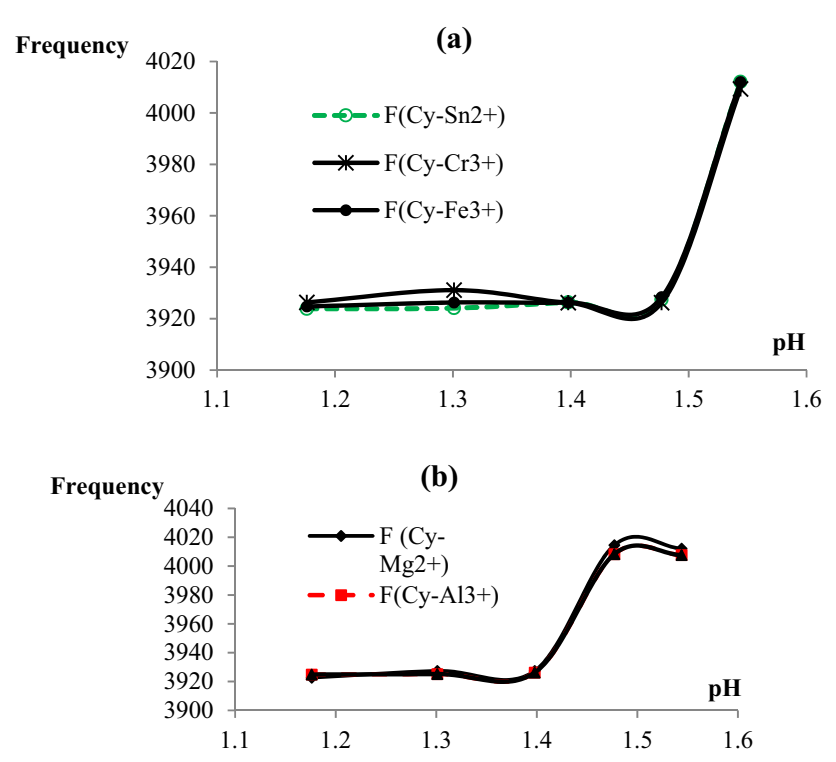

Fig. 6 Changes of Frequency $(\mathrm{F})$ versus $\mathrm{pH}$ for a [cyanidin-metallic cations of $\left(\mathrm{Sn}^{2+}, \mathrm{Cr}^{3+}\right.$ and $\left.\mathrm{Fe}^{3+}\right)$ ] cluster chelation and $\mathbf{b}$ [cyanidinmetallic cations of $\left.\left(\mathrm{Mg}^{2+}, \mathrm{Al}^{3+}\right)\right]$ chelation in the weak acidic media by different concentrations of $\mathrm{H}^{+}$at $300 \mathrm{~K}$ in Iranian Qara Qat fruit anthocyanin-metal cation chelation of cyanidin-Al ${ }^{3+}$, delphinidin- $\mathrm{Al}^{3+}$, and petunidin- $\mathrm{Al}^{3+}$ in optimized weak acidic media approves the stability and color of these structures. The principal frequency vibrational modes have been illustrated based on the stability and color of various anthocyanin-metal cation chelation (Table 4).

In the next step, the atomic charge of indicated atoms in [anthocyanin-metallic cations of $\mathrm{Mg}^{2+}, \mathrm{Al}^{3+}, \mathrm{Ga}^{3+}, \mathrm{Sn}^{2+}$, $\mathrm{Cr}^{3+}$ and $\left.\mathrm{Fe}^{3+}\right)$ ] cluster chelation in Iranian Qara Qat fruit has been evaluated as the active parts of the molecules which play an important role for the electron charge transfer toward producing a range of various colors in water medium (Scheme 2, Figs. 1, 2, Table 5).

In Fig. 7a-c, it has been plotted the changes of atomic charge of labeled oxygen atoms and metal cations through optimized [anthocyanin-metallic cations of $\mathrm{Mg}^{2+}, \mathrm{Al}^{3+}$, $\mathrm{Ga}^{3+}, \mathrm{Sn}^{2+}, \mathrm{Cr}^{3+}$ and $\left.\mathrm{Fe}^{3+}\right)$ ] cluster chelation in Iranian Qara Qat fruit (Scheme 1, Figs. 1, 2); so, the results of Table 5 in a polar medium of water solution comparison to gas phase declare the stability and color of these compounds in the natural products of vegetables and fruits (Fig. 7a-c).

The outlook of Fig. $7 \mathrm{a}-\mathrm{c}$ recommends the reason for existing observed various results of [anthocyanin-metallic cations of $\left(\mathrm{Mg}^{2+}, \mathrm{Al}^{3+}, \mathrm{Ga}^{3+}, \mathrm{Sn}^{2+}, \mathrm{Cr}^{3+}\right.$ and $\left.\left.\mathrm{Fe}^{3+}\right)\right]$ cluster chelation in Iranian Qara Qat fruit which are principally 


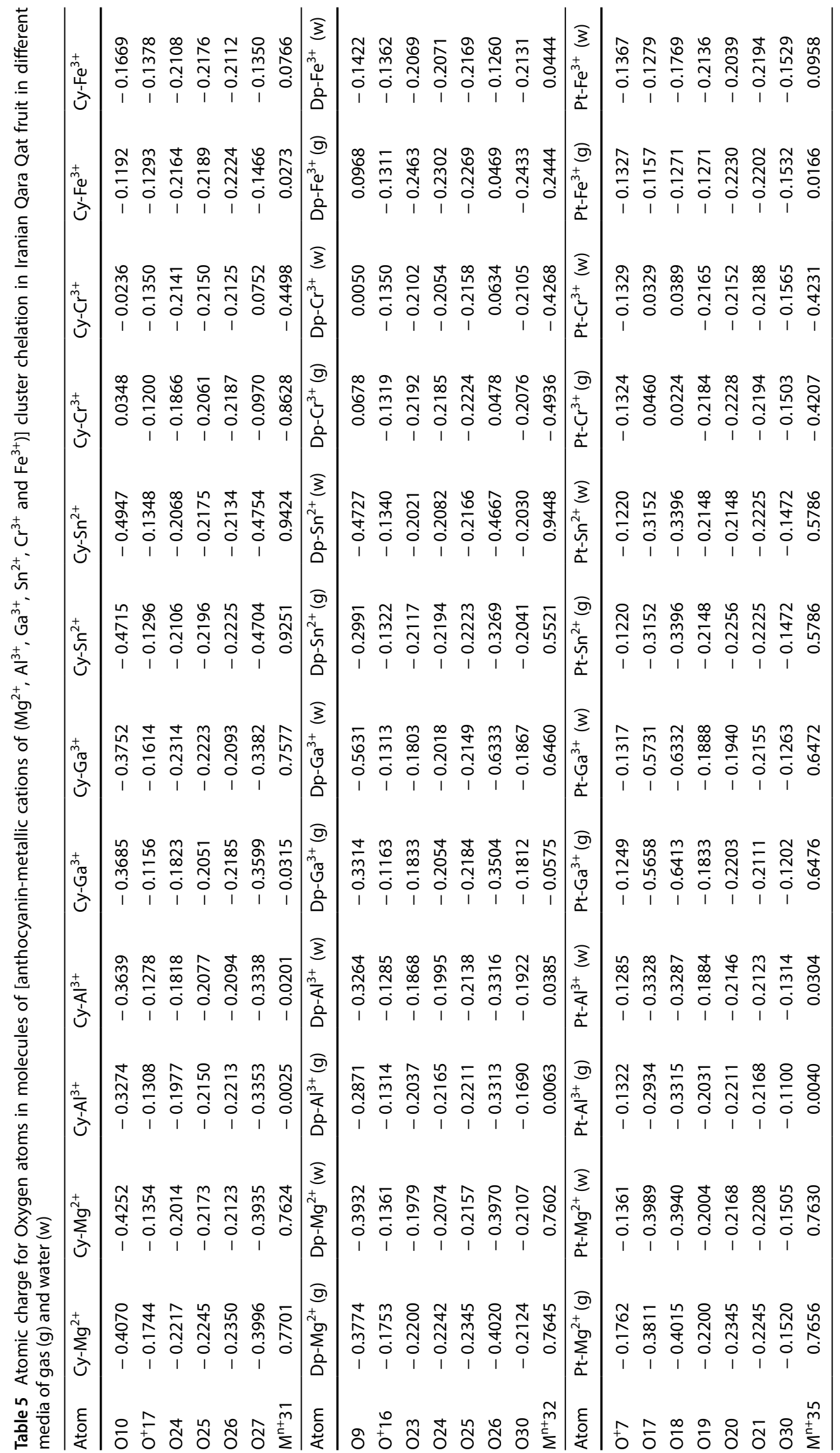


linked to the position of active cites of labeled oxygen atoms and metal cations in these molecules which move the charge of electrons in aromatic cyclic chains because of water polar medium in contrast to gas phase and the lowest deviation for two media of water and gas has been indicated for anthocyanin-Mg ${ }^{2+}$ (Fig. 7 a-c).

In fact, the spin density and partial charges have been obtained by fitting the electrostatic potential to fixed charge of $\mathrm{O}_{17}^{+}, \mathrm{O}_{16}^{+}$, and $\mathrm{O}_{7}^{+}$cations for cyanidin- $\mathrm{M}^{\mathrm{n}+}(31)$, delphinidin- $\mathrm{M}^{\mathrm{n}+}(32)$ and petunidin- $\mathrm{M}^{\mathrm{n}+}(35)$, respectively (Table 5, Fig. 7a-c); therefore, the electrophilic groups of cyanidin, delphinidin anthocyanin pigments conduct us to find the reason for the activity and the stability of these structures in the natural products.

\section{Conclusion}

In this study, the anthocyanins of cyanidin (Cy), delphinidin (Dp) and petunidin (Pt) with a large chelation in the active zone of these structures by metallic cations of $\left(\mathrm{Mg}^{2+}, \mathrm{Al}^{3+}, \mathrm{Ga}^{3+}, \mathrm{Sn}^{2+}, \mathrm{Cr}^{3+}\right.$ and $\left.\mathrm{Fe}^{3+}\right)$ metallic cations make a variety range of colors under acidic $\mathrm{pH}$; as divalent $\mathrm{Mg}^{2+}$ has shown various physicochemical properties considering its optimized geometry optimization as the bond length of oxygen- $-\mathrm{Mg}^{2+} \approx(1.9 \AA)$ and the bond angle of oxygen- $\mathrm{Mg}^{2+}$-oxygen $\approx\left(112^{\circ}\right)$ while it has been indicated the bond length of oxygen- $\mathrm{M}^{3+} \approx(1.8 \AA)$ and bond angle of oxygen- $\mathrm{M}^{3+}$-oxygen $\approx\left(120^{\circ}\right)$ for trivalent metallic cations of $\left(\mathrm{Mg}^{2+}, \mathrm{Al}^{3+}, \mathrm{Ga}^{3+}, \mathrm{Sn}^{2+}, \mathrm{Cr}^{3+}\right.$ and $\left.\mathrm{Fe}^{3+}\right)$ metallic cations with more electron rich metal ions caused shifts and hue changes in the stability of color and structure.

Moreover, we have found that [anthocyanin-metallic cations of $\left(\mathrm{Mg}^{2+}, \mathrm{Al}^{3+}, \mathrm{Ga}^{3+}, \mathrm{Sn}^{2+}, \mathrm{Cr}^{3+}\right.$ and $\left.\left.\mathrm{Fe}^{3+}\right)\right]$ cluster chelation is based on the axes of active zones of specified oxygen atoms and metallic cations in these complexes which shift the electronic charges in aromatic cyclic chains because of water dielectric constant in contrast to gas medium. The spin density and partial charges have been gained by establishing the electrostatic potential to fix charge of $\mathrm{O}_{17^{\prime}}^{+} \mathrm{O}_{16^{\prime}}^{+}$and $\mathrm{O}_{7}^{+}$cations for cyanidin- $\mathrm{M}^{\mathrm{n}+}(31)$, delphinidin- $\mathrm{M}^{\mathrm{n}+}(32)$ and petunidin- $\mathrm{M}^{\mathrm{n}+}(35)$, respectively based on the electrophilic groups of cyanidin, delphinidin and petunidin of anthocyanin colorful pigments which show the activity and the stability of these compounds toward the natural material. Generally, anthocyanin is capable to chelate the $\mathrm{M}^{\mathrm{n}+}$ through indicating the shift in their frequency and absorbance spectra which are affected by several factors including the anthocyanin structure, $\mathrm{pH}$ which is the important environmental factor in the expressed color of the solutions, and also the atomic configuration of the metallic cations.

Divalent $\mathrm{Mg}^{2+}$ was found to impact anthocyanin minimally with raising electron density in different $\mathrm{pH} ; \mathrm{Sn}^{2+} \approx$ $\mathrm{Fe}^{3+} \approx \mathrm{Ga}^{3+}>\mathrm{Al}^{3+}>\mathrm{Cr}^{3+}>>\mathrm{Mg}^{2+}$

Using Beer Lambert law on [anthocyanin-metallic cations of $\left(\mathrm{Mg}^{2+}, \mathrm{Al}^{3+}, \mathrm{Ga}^{3+}, \mathrm{Sn}^{2+}, \mathrm{Cr}^{3+}\right.$ and $\left.\left.\mathrm{Fe}^{3+}\right)\right]$ cluster chelation of cyanidin, delphinidin, and petunidin pigments in Iranian Qara Qat fruit using theoretical methods illustrates absorbance factor in two media of gas and water and then unravels the stabilization energy and geometry which have been impacted by IR theoretical modeling toward the thermodynamic properties and the electronic structural of optimized [anthocyanin-metallic cations of $\mathrm{Mg}^{2+}$, $\mathrm{Al}^{3+}, \mathrm{Ga}^{3+}, \mathrm{Sn}^{2+}, \mathrm{Cr}^{3+}$ and $\left.\left.\mathrm{Fe}^{3+}\right)\right]$ cluster chelation in Iranian Qara Qat fruit resulting of metal chelation.

The results have exhibited that such extrapolation Schemes 1, 2, 3 and 4 significantly overestimate [anthocyanin-metallic cations of $\mathrm{Mg}^{2+}, \mathrm{Al}^{3+}, \mathrm{Ga}^{3+}, \mathrm{Sn}^{2+}, \mathrm{Cr}^{3+}$ and $\left.\mathrm{Fe}^{3+}\right)$ ] cluster chelation in Iranian Qara Qat fruit by sharp parts of electrophilic molecules in weak acidic media with different concentrations of $\mathrm{H}^{+}$which are the most active particles at the applied compounds in this project. 
(a)

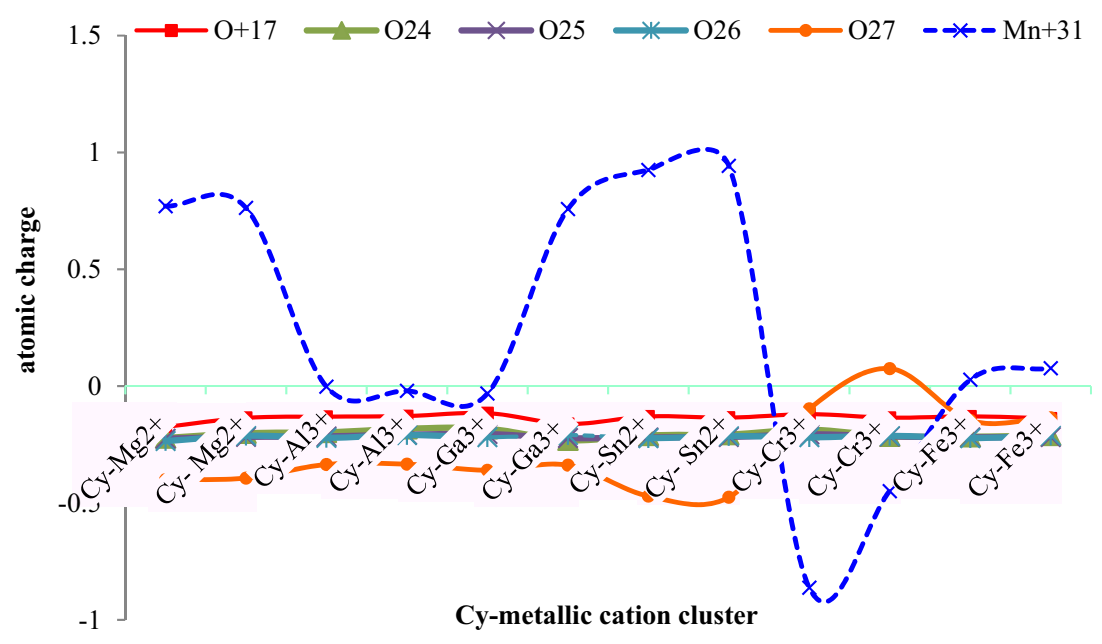

(b)

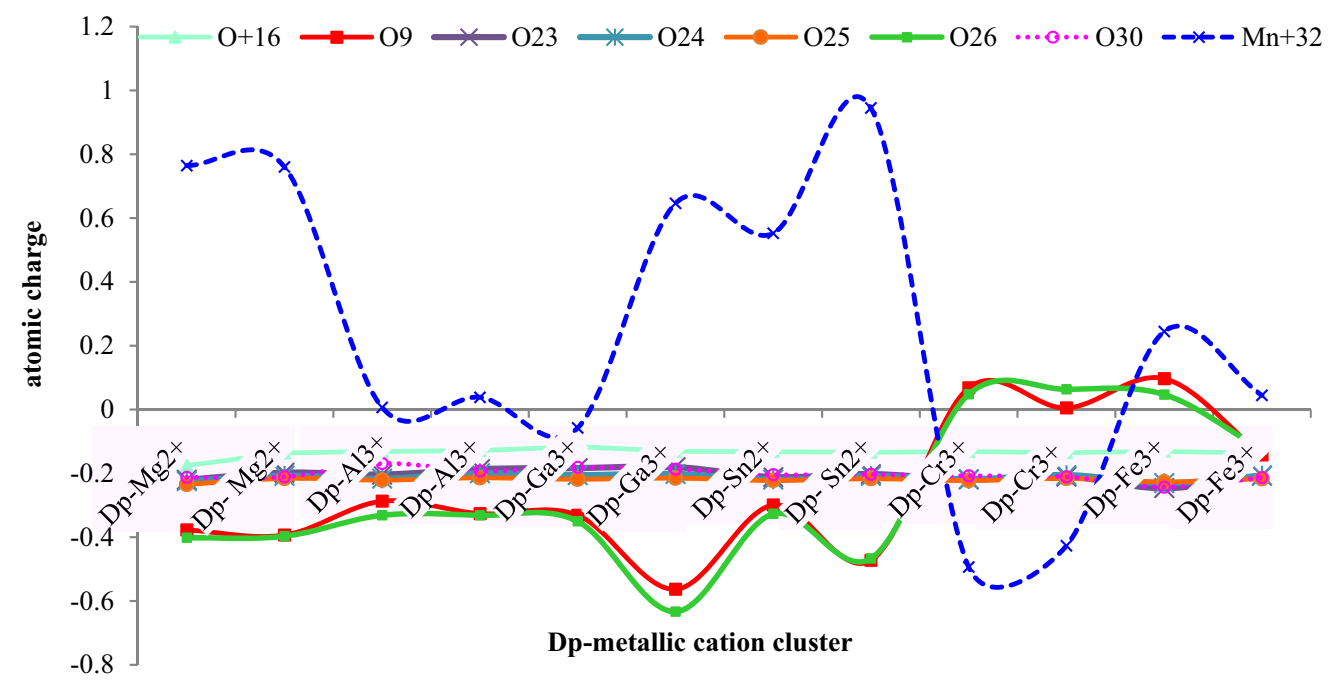

(c)

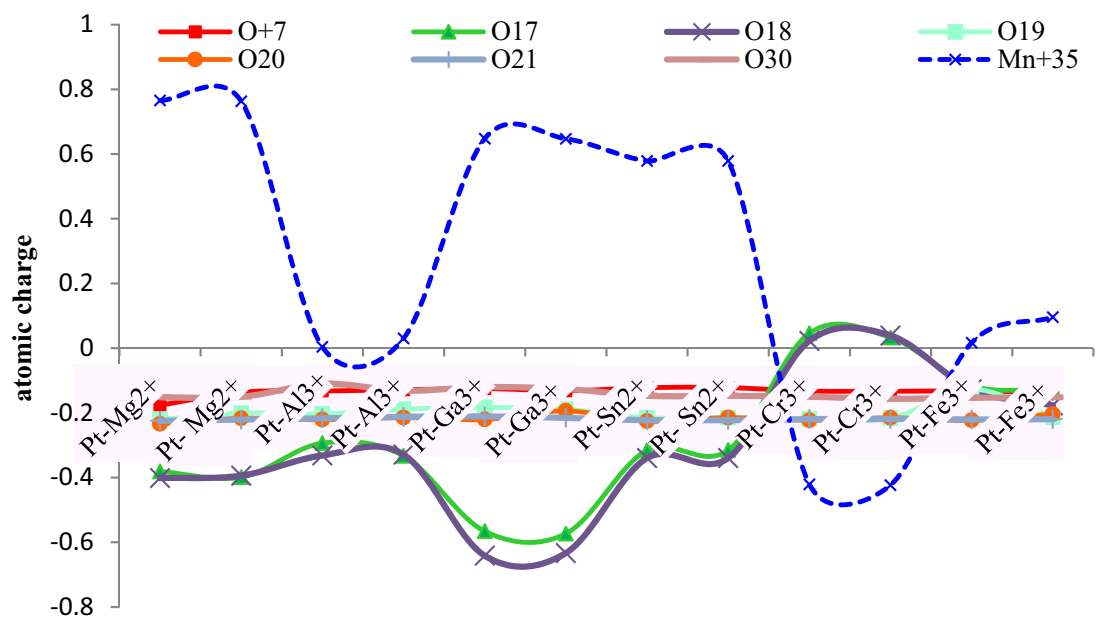

Pt-metallic cation cluster 
4Fig. 7 Comparison of atomic charge versus labeled oxygen atoms and metal cations through optimized a [cyanidin-metallic cations of $\left(\mathrm{Mg}^{2+}, \mathrm{Al}^{3+}, \mathrm{Ga}^{3+}, \mathrm{Sn}^{2+}, \mathrm{Cr}^{3+}\right.$ and $\left.\left.\mathrm{Fe}^{3+}\right)\right], \mathbf{b}$ [delphinidin-metallic cations of (magnesium, aluminum, gallium, tin, chrome and iron)] and $\mathbf{c}$ [petunidin-metallic cations of (magnesium, aluminum, gallium, tin, chrome and iron)] cluster chelation of Iranian Qara Qat fruit in two media of gas and water

\section{Declarations}

Conflict of interest The authors declare that they have no competing interests.

Open Access This article is licensed under a Creative Commons Attribution 4.0 International License, which permits use, sharing, adaptation, distribution and reproduction in any medium or format, as long as you give appropriate credit to the original author(s) and the source, provide a link to the Creative Commons licence, and indicate if changes were made. The images or other third party material in this article are included in the article's Creative Commons licence, unless indicated otherwise in a credit line to the material. If material is not included in the article's Creative Commons licence and your intended use is not permitted by statutory regulation or exceeds the permitted use, you will need to obtain permission directly from the copyright holder. To view a copy of this licence, visit http://creativecommons. org/licenses/by/4.0/.

\section{References}

1. Quina FH, Bastos EL (2018) Chemistry inspired by the colors of fruits, flowers and wine. An Acad Bras Cienc 90:681

2. Castaneda-Ovando A, Pacheco-Hernandez ML, Paez-Hernandez ME, Rodriguez JÁ, Galan-Vidal CA (2009) Chemical studies of anthocyanins: a review. Food Chem 113:859

3. Pina F, Oliveira J, Freitas V (2015) Anthocyanins and derivatives are more than flavylium cations. Tetrahedron 71:3107

4. Castañeda-Ovando A, de Lourdes Pacheco-Hernández M, PáezHernández E et al (2009) Chemical studies of anthocyanins: a review. Food Chem 113(4):859-871

5. Seeram NP, Momin RA, Nair MG et al (2001) Cyclooxygenase inhibitory and antioxidant cyanidin glycosides in cherries and berries. Phytomedicine 8(5):362-369

6. Cevallos-Casals BA, Cisneros-Zevallos L (2003) Stoichiometric and kinetic studies of phenolic antioxidants from Andean purple corn and red-fleshed sweetpotato. J Agric Food Chem 51(11):3313-3319

7. Katsumoto Y, Fukuchi-Mizutani M, Fukui $Y$ et al (2007) Engineering of the rose flavonoid biosynthetic pathway successfully generated blue-hued flowers accumulating delphinidin. Plant Cell Physiol 48(11):1589-1600

8. Bąkowska-Barczak A (2005) Acylated anthocyanins as stable, natural food colorants-a review. Pol J Food Nutr Sci 14/55(2):107-116

9. Robinson GM, Robinson R (1932) A survey of anthocyanins II. Biochemical J 6(5):1647

10. Jaakola $L$ (2013) New insights into the regulation of anthocyanin biosynthesis in fruits. Trends Plant Sci 18(9):477-483

11. Olsson ME, Gustavsson $\mathrm{KE}$, Andersson $\mathrm{S}$, Nilsson $\AA$, Duan RD (2004) Inhibition of cancer cell proliferation in vitro by fruit and berry extracts and correlations with antioxidant levels. J Agric Food Chem 52:7264-7271

12. Hassan HA, Abdel-Aziz AF (2010) Evaluation of free radicalscavenging and anti-oxidant properties of black berry against fluoride toxicity in rats. Food Chem Toxicol 48:1999-2004

13. Duthie SJ (2007) Berry phytochemicals, genomic stability and cancer: evidence for chemoprotection at several stages in the carcinogenic process. Mol Nutr Food Res 51(6):665-674

14. Ardalan T, Ardalan P, Monajjemi M (2014) Nano theoretical study of a $\mathrm{C} 16$ cluster as a novel material for vitamin C carrier. Fuller Nanotub Carbon Nanostruct 22(8):687-708

15. Taylor LP, Grotewold E (2005) Flavonoids as developmental regulators. Curr Opin Plant Biol 8:317-323

16. Peer WA, Murphy AS (2007) Flavonoids and auxin transport: modulators or regulators? Trends Plant Sci 12:556-563

17. Monajjemi M, Ahmadianarog M (2014) Carbon nanotube as a deliver for sulforaphane in Broccoli vegetable in point of nuclear magnetic resonance and natural bond orbital specifications. J Comput Theor Nanosci 11(6):1465-1471

18. Hudson EA, Dinh PA, Kokubun T, Simmonds MS, Gescher A (2000) Cancer epidemiology. Biomarkers Prev 9:1163-1170

19. Harborne JB (1998) Phenolic compounds. In: Harborne JB (ed) Phytochemical methods, a guide to modern techniques of plant analysis, 3rd edn. Chapman \& Hall, New York, pp 66-74

20. Wenzel J, Wang L, Horcasitas S, Warburton A, Constine S, Kjellson A, Cussans K, Ammerman M, Samaniego CS (2020) Influence of supercritical fluid extraction parameters in preparation of black chokeberry extracts on total phenolic content and cellular viability. Food Sci Nutr 8(7):3626-3637

21. Heredia FJ, Francia-Aricha EM, Rivas-Gonzalo JC, Vicario IM, Santos-Buelga C (1998) Chromatic characterization of anthocyanins from red grapes-l. pH effect. Food Chem 63:491-498

22. Ahmadiani N, Robbins RJ, Collins TM et al (2014) Anthocyanins contents, profiles, and color characteristics of red cabbage extracts from different cultivars and maturity stages. J Agric Food Chem 62(30):7524-7531

23. Sidor A, Gramza-Michałowska A (2019) Black Chokeberry Aronia melanocarpa L.-a qualitative composition, phenolic profile and antioxidant potential. Molecules 24(20):3710

24. Koss-Mikołajczyk I, Kusznierewicz B, Bartoszek A (2019) The relationship between phytochemical composition and biological activities of differently pigmented varieties of berry fruits; comparison between embedded in food matrix and isolated anthocyanins. Foods 8(12):646

25. Borkowski T, Szymusiak H, Gliszczynska-Swiglo A, Tyrakowska B (2005) The effect of 3-O- $\beta$-glucosylation on structural transformations of anthocyanidins. Food Res Int 38:1031-1037

26. Freitas AA, Shimizu K, Dias LG, Quina FH (2007) A computational study of substituted flavylium salts and their quinonoidal conjugate-bases: S0 -> S1 electronic transition, absolute pKa and reduction potential calculations by DFT and semiempirical methods. J Braz Chem Soc 18(8):1537-1546

27. Sigurdson GT, Tang P, Giusti MM (2017) Natural colorants: food colorants from natural sources. Annu Rev Food Sci Technol 8:261

28. Freitas AA, Dias LG, Maçanita AAL, Quina FH (2011) Substituent effects on the $\mathrm{pH}$-dependent multiequilibria of flavylium salt analogs of anthocyanins: substituent effects on anthocyanin analogs. J Phys Org Chem 24:1201

29. Ananga A, Georgiev V, Ochieng J, Phills B, Tsolova V (2013) Production of anthocyanins in grape cell cultures : a potential source of raw material for pharmaceutical, food, and cosmetic industries. In: Puljuha D, Sladonja B (eds) The Mediterranean genetic code-grapevine and olive, 1st edn. InTech, Rijeka, Croatia, pp 247-288 
30. Glińska S, Bartczak M, Oleksiak S, Wolska A, Gabara B, Posmyk $M$, Janas K (2007) Effects of anthocyanin-rich extract from red cabbage leaves on meristematic cells of Allium cepa L. roots treated with heavy metals. Ecotoxicol Environ Saf 68(3):343-350

31. Schreiber HD, Swink AM, Godsey TD (2010) The chemical mechanism for $\mathrm{Al}^{3+}$ complexing with delphinidin: a model for the bluing of hydrangea sepals. J Inorg Biochem 104(7):732-739

32. Dangles O, Elhabiri M, Brouillard R (1994) Kinetic and thermodynamic investigation of the aluminium-anthocyanin complexation in aqueous solution. J Chem Soc Perkin Trans 2(12):2587

33. Cabrita L, Fossen T, Andersen ØM (2000) Colour and stability of the six common anthocyanidin 3-glucosides in aqueous solutions. Food Chem 68(1):101-107

34. Fossen T, Cabrita L, Andersen OM (1998) Colour and stability of pure anthocyanins influenced by $\mathrm{pH}$ including the alkaline region. Food Chem 63(4):435-440

35. Buchweitz M, Carle R, Kammerer DR (2012) Bathochromic and stabilizing effects of sugar beet pectin and an isolated pectic fraction on anthocyanins exhibiting pyrogallol and catechol moieties. Food Chem 135(4):3010-3019

36. Yoshida K, Mori M, Kondo T (2009) Blue flower color development by anthocyanins: from chemical structure to cell physiology. Nat Prod Rep 26(7):884-915

37. Frisch MJ, Trucks GW, Schlegel HB, Scuseria GE, Robb MA, Cheeseman JR, Scalmani G, Barone V, Mennucci B, Petersson GA, Nakatsuji H, Caricato M, Li X, Hratchian HP, Izmaylov AF, Bloino J, Zheng G, Sonnenberg JL, Hada M, Ehara M, Toyota K, Fukuda R, Hasegawa J, Ishida M, Nakajima T, Honda Y, Kitao O, Nakai $\mathrm{H}$, Vreven T, Montgomery JA Jr, Peralta JE, Ogliaro F, Bearpark M, Heyd JJ, Brothers E, Kudin KN, Staroverov VN, Kobayashi R, Normand J, Raghavachari K, Rendell A, Burant JC, lyengar SS, Tomasi J, Cossi M, Rega N, Millam JM, Klene M, Knox JE, Cross JB, Bakken V, Adamo C, Jaramillo J, Gomperts R, Stratmann RE, Yazyev O, Austin AJ, Cammi R, Pomelli C, Ochterski JW, Martin RL, Morokuma K, Zakrzewski VG, Voth GA, Salvador P, Dannenberg JJ, Dapprich S, Daniels AD, Farkas O, Foresman JB, Ortiz JV, Cioslowski J, Fox DJ (2010) Gaussian 09, Revision B.01. Gaussian Inc., Wallingford

38. Martin K, Andrew McCammon J (2002) Erratum: Molecular dynamics simulations of biomolecules. Nat Struct Biol 9:788

39. Wilfred F, Gunsteren V, Berendsen HJC (1990) Computer simulation of molecular dynamics: methodology, applications, and perspectives in chemistry. Angew Chem Int Ed English 29(9):992-1023

40. Ni W, Li G, Zhao J, Cui J, Wang R, Gao Z, Liu Y (2018) Use of Monte Carlo simulation to evaluate the efficacy of tigecycline and minocycline for the treatment of pneumonia due to carbapenemase-producing Klebsiella pneumonia. Infect Dis (Lond) 50(7):507-513

41. Andrews CW, Wisowaty J, Davis AO, Crouch RC, Martin GE (1995) Molecular modeling, NMR spectroscopy, and conformational analysis of $3^{\prime}, 4^{\prime}$-anhydrovinblastine. J Heterocycl Chem 32(3):1011-1017
42. Monajjemi M, Honarparvar B, Nasseri SM, Khaleghian M (2009) NQR and NMR study of hydrogen bonding interactions in anhydrous and monohydrated guanine cluster model: a computational study. J Struct Chem 50(1):67-77

43. Monajjemi M, Ghiasi R, Sadjadi MS (2003) Metal-stabilized rare tautomers: N4 metalated cytosine ( $\mathrm{M}=\mathrm{Li}, \mathrm{Na}, \mathrm{K}, \mathrm{Rb}$ and $\mathrm{Cs}$ ), theoretical views. Appl Organomet Chem 17(8):635-640

44. Wilfred F, Berendsen HJC (1990) Computer simulation of molecular dynamics methodology, applications, and perspectives in chemistry. Angew Chem Int Ed English 29:992-1023

45. Karplus M, Petsko GA (1990) Molecular dynamics simulations in biology. Nature 347:631-639

46. Cohen G, Eisenberg H (1968) Deoxyribonueleate solutions: Sedimentation in a density gradient, partial specific volumes, density and refractive index increments, and preferential interactions. Biopolymers 6:1077

47. Beak P, Covington JB, Smith SG, White JM, Zeiger JM (1980) Displacement of protomeric equilibriums by self-association: hydroxypyridine-pyridone and mercaptopyridine-thiopyridone isomer pairs. J Org Chem 45:1354

48. Kirkwood JG (1934) On the theory of strong electrolyte solutions. J Chem Phys 2:767

49. Kirkwood JG (1939) The dielectric polarization of polar liquids. J Chem Phys 7:911

50. Onsager $L$ (1936) Electric moments of molecules in liquids. J Am Chem Soc 58:1486

51. Wong MA, Frisch MJ, Wiberg KB (1991) Solvent effects. 1. The mediation of electrostatic effects by solvents. J Am Chem Soc 113:4776

52. Wong MA, Frisch MJ, Wiberg KB (1992) Solvent effects. 2. Medium effect on the structure, energy, charge density, and vibrational frequencies of sulfamic acid. J Am Chem Soc 114:523

53. van der Kamp MW, Mulholland AJ (2013) Combined quantum mechanics/molecular mechanics (QM/MM) methods in computational enzymology. Biochemistry 52(16):2708-2728

54. Gadda G, Sobrado P (2018) Kinetic solvent viscosity effects as probes for studying the mechanisms of enzyme action. Biochemistry 57(25):3445-3453

55. Kunsági-Máté S, Ortmann E, Kollár L, Szabó K, Nikfardjam MP (2008) Effect of ferrous and ferric ions on copigmentation in model solutions. J Mol Struct 891(1-3):471-474

56. Estévez L, Otero N, Mosquera RA (2011) Molecular structure of cyanidin metal complexes: $\mathrm{Al}(\mathrm{III})$ versus $\mathrm{Mg}$ (II). Theoret Chem Acc 128(4):485-495

57. Mason RP (2013) Chemical thermodynamics and metal (loid) complexation in natural waters. In: Mason RP (ed) Trace metals in aquatic systems, 1st edn. Blackwell Publishing (John Wiley \& Sons Ltd.), Chichester, West Sussex, pp 49-123

Publisher's Note Springer Nature remains neutral with regard to jurisdictional claims in published maps and institutional affiliations. 